\title{
READ HER LIPS: AN ARGUMENT FOR A VERBAL CONSENT STANDARD IN RAPE
}

\author{
LANI ANNE REMICK $\dagger$
}

\begin{abstract}
Always take "no" for an answer. Always stop when asked to stop. Never assume "no" means "yes." If her lips tell you "no" but there's "yes" in her eyes, keep in mind that her words, not her eyes, will appear in the court transcript. ${ }^{1}$
\end{abstract}

Violence against women has reached an all-time high. ${ }^{2}$ An estimated fifteen to forty percent of all women are victims of attempted or completed rapes at some point in their lifetimes. ${ }^{3}$ Most of their rapists are never criminally punished. ${ }^{4}$

† A.B. 1989, Princeton University; J.D. Candidate 1993, University of Pennsylvania. I extend many thanks to Professor Stephen J. Morse for his helpful suggestions on earlier versions of this Comment. I also owe my deepest gratitude to Todd Ewan for his steadfast support.

1 Asa Baber, The Stud Muffin Quiz, PlaYBoy, June 1992, at 36, 36.

${ }^{2}$ See Victims of Rape: Hearing Before the House Select Comm. on Children, Youth, and Families, 101st Cong., 2d Sess. 5 (1990) [hereinafter House Hearings] (statement of Hon. George Miller including fact sheet entitled "Victims of Rape").

${ }^{3}$ See id.

4 There are several reasons why most rapists escape the criminal justice system. To begin with, 60 to $90 \%$ of sexual assault victims do not report the crime to the police. See Mary Nemeth et al., Chilling the Sexes: Women's Growing Militancy About Harassment and Date Rape Alarms Many Men, MACLEAN's, Feb. 17, 1992, at 42, 43; see also Fred Bruning, A Lousy Deal for Women-and Men, MACLEAN's, Aug. 12, 1991 at 9, 9 ("Authorities say that date rape is among the most unreported felonies in the United States, and everyone knows that there are plenty of Neanderthal pretty boys and self-adoring Casanovas who persist in thinking that women 'want it,' whether the women in question have been asked their opinions or not.") (article reviewing the movie Thelma $\mathcal{E}^{2}$ Louise). Reasons for not reporting include fear of being disbelieved, lack of faith in the criminal justice system, and fear of the alleged assailant. See Nemeth et al., supra, at 43. In addition, many rape victims fail to recognize their experiences as rapes. See infra notes $145-51$ and accompanying text. Of those rapes that are reported, perhaps as many as half are never prosecuted. See infra note 152 and accompanying text. One reason for this underprosecution is that police frequently fail to list rape victims' reports as rapes because they regard them as false or believe that the victim precipitated the rape. See House Hearings, supra note 2, at 6 (citing one study of statistics sent to the FBI which showed that only $53.8 \%$ of rape reports filed by women were listed as rapes by the police). Moreover, even when prosecuted, rape has a significantly lower conviction rate than other crimes. The House Report listed the following statistics: 91,460 rapes were reported to the police nationwide in 1986, but only 19,685 individuals were convicted of rape that year; $71 \%$ of those arrested and charged with rape in Manhattan in 1986 had their cases dismissed although the average dismissal rate for all felons was 37\%; in Washington, D.C., the dismissal rate for rapists was $50 \%$ compared with an average for all felonies 
The criminal justice system's failure to bring most rapists to justice means that women's right to decide "who may touch their bodies, when, and under what circumstances ${ }^{\text {} 5}$ is often unenforceable. One of the causes of this problem is that the law of rape does not recognize women's right to sexual autonomy as absolute. Instead, rape law reflects the sexually coercive society in which it operates. ${ }^{6}$ Although frowning upon aggressive sexual behavior at the extremes, our male-dominated society accepts a certain amount of coercion, aggression or violence against women as a normal, even desirable, part of sexual encounters. ${ }^{7}$ Similarly, the law of rape is founded on a paradigm of violent stranger rape which fails to clearly proscribe less violent rapes or rapes in which some elements of a consensual sexual encounter are present. ${ }^{8}$ An estimated sixty to eighty percent of all rapes fit this description. ${ }^{9}$ The inability of victims of these "nontraditional" rapes to vindicate their rights through use of the criminal system is thus one of the biggest impediments to the comprehensive protection of female sexual autonomy under the law of rape. ${ }^{10}$ If such protection is to be afforded, therefore, "[m]uch, much more needs to be done.... The message that should go out today is that rape is a crime, whether it be date rape, intrafamiliar rape, acquaintance rape, stranger rape or spousal rape. Rape is rape."11

This Comment suggests a change in the law of rape that would bring all instances of nontraditional rape clearly within the boundaries of the criminal law. Its chosen vehicle for change is a redefinition of the consent standard. In searching for a solution to the current legal system's inadequate protection of women, several commentators have concluded that "the road to that solution

of $29 \%$. See id. at 7 .

${ }^{5}$ State ex rel. M.T.S., 609 A.2d 1266, 1278 (N.J. 1992).

${ }^{6}$ See infra notes 154-66 and accompanying text.

7 See infra notes $155-60$ and accompanying text.

${ }^{8}$ See Susan Estrich, Rape, 95 YALE L.J. 1087, 1092 (1986).

${ }^{9} \mathrm{See}$ HOUSE HEARINGS, supra note 2 , at 7.

${ }^{10}$ Susan Estrich, who coined the term "non-traditional rape," commented on the law's failure to punish perpetrators of such rapes:

In such cases, the law, as reflected in the opinions of the courts, the interpretation, if not the words, of the statutes, and the decisions of those within the criminal justice system, often tell us that no crime has taken place and that fault, if any is to be recognized, belongs with the woman.

Estrich, supra note 8, at 1092.

11 House Hearings, supra note 2, at 55 (prepared statement of Wanda KeyesRobinson, Division Chief, Sexual Offense Unit, Office of the State's Attorney for Baltimore City, Baltimore, Md.). 
presents itself clearly enough as a need for a reformulation of the criterion of consent. ${ }^{n 12}$ Other reformers call for simplicity and clarity in a new criterion, noting that " [c]ontinuous juggling of the elements of the crime by courts and commentators reflects an urge toward administrative simplicity, a search for an external standard by which to measure the subjective element of nonconsent. [Yet] ... this interplay reveals a conviction that the central substantive issue in rape is consent. ${ }^{13}$

In answer to the call for a new, clearer consent standard, this Comment proposes a rape law based on a norm of affirmative verbal consent. Under this standard, "no" would mean "no," "yes" would mean "yes," and the lack of any verbal communication as to consent would be presumed to mean "no." In more specific terms, a "no" or its verbal equivalent would be dispositive of the issue of consent, as would a freely-given "yes" or its verbal equivalent. The lack of a "yes" or its verbal equivalent would raise a presumption of nonconsent. Such a standard would criminalize even "nonaggravated sexual assault, [that is,] nonconsensual sex that does not involve physical injury, or the explicit threat of physical injury. "14 By establishing the threshold for rape at this level, the suggested standard clearly incorporates all instances of nontraditional rape. ${ }^{15}$ It also underscores the gravity of the harm of more traditional violent stranger rape. Finally, rather than simply mirroring our sexually coercive society, such a law declares that a woman's right to sexual autonomy is absolute.

It is because rape law currently operates in the context of a sexually coercive society and because rape victims are overwhelmingly female that this Comment argues for a change in the law on the

12 Lois Pineau, Date Rape: A Feminist Analysis, 8 LAW \& PHIL. 217, 221 (1989). Pineau adds that " $[i] t$ is patent that a criterion [of consent] that collapses whenever the crime itself succeeds will not suffice." Id. For other pieces treating consent as the central issue in the law of rape, see e.g., Robin D. Wiener, Shifting the Communication Burden: A Meaningful Consent Standard in Rape, 6 HARV. WOMEN's L.J. 143 (1983); Victoria J. Dettmar, Comment, Culpable Mistakes in Rape: Eliminating the Defense of Unreasonable Mistake of Fact as to Victim Consent, 89 DICK. L. REV. 473 (1985); Lucy R. Harris, Comment, Towards a Consent Standard in the Law of Rape, 43 U. CHI. L. REV. 613, 620 (1976); Christina M. Tchen, Comment, Rape Reform and a Statutory Consent Defense, 74 J. CRIM. L. \& CRIMINOLOGY 1518 (1983).

13 Harris, supra note 12 , at 620.

14 Pineau, supra note 12, at 217.

${ }^{15}$ This is not to suggest, however, that nontraditional rapes are always nonviolent. To the contrary, many acquaintance, date, and other nonstranger rapes are characterized by extreme violence. 
ground of assuring sexual autonomy for women. ${ }^{16}$ This is not to suggest, however, that the consent standard proposed here should not be applied in a gender-neutral manner. To the contrary, such an approach is wholeheartedly supported. ${ }^{17}$ Recent estimates suggest that at least ten percent of all rape victims are men. ${ }^{18}$ Applied in a gender-neutral manner, the new consent standard suggested here would protect men's sexual autonomy as much as it would women's. Moreover, even as presented (in terms of women as rape victims and men as perpetrators of rape) the standard has a major advantage for men in that it clarifies the murky line between nonconsensual sex and rape that is a present source of male consternation. ${ }^{19}$ Therefore, despite the terms in which it is couched, this Comment should not be seen as promoting some sort of "special" protection for women at the expense of men. Instead, its proposal is intended to secure adequate legal protection from rape for both men and women, thus insuring sexual autonomy for all.

Part I will discuss how the current prima facie elements of and defenses to rape would have to be altered in order to realize a new standard based on affirmative verbal consent. These alterations will be justified in terms of insuring female autonomy, including sexual autonomy, and bringing the treatment of rape victims into conformity with that of victims of other offenses for which nonconsent is an element. Part I will further offer suggestions for the effectuation of such changes through both the adoption of new statutory language and the reinterpretation of existing statutes. Finally, an analysis of mens rea and culpability will show that the punishment of those who violate a rape law predicated on affirmative verbal consent can be justified according to commonly accepted notions of criminal culpability.

16 It is also for these reasons that victims and alleged victims of rape will be referred to as female and rapists or alleged rapists will be referred to as male.

${ }^{17}$ Thirty-seven states' statutes currently employ gender-neutral terminology for both offenders and victims. Louisiana statute presupposes a male offender and a male or female victim. The remaining states and the District of Columbia treat rape as an offense perpetrated by a male offender against a female victim. See Patricia Searles \& Ronald J. Berger, The Current Status of Rape Reform Legislation: An Examination of State Statutes, 10 WOMEN'S RTS. L. REP. 25, 32 (1987).

${ }^{18}$ See Robin Warshaw, I NeVer Called It RAPe 3, 97-98 (1988). For a more extensive discussion of male rape, see generally RICHIE J. MCMULLEN, MALE RAPE: BREAKING THE SILENCE ON THE LAST TABOO (1990) (emphasis on English law).

${ }^{19}$ See infra notes $134-43$ and accompanying text. 
Part II will examine the ramifications of a rape standard characterized by the changes suggested in Part I. It will argue, as mentioned above, that whereas current rape law merely reflects our sexually coercive society, a standard based on affirmative verbal consent would prescribe sexual equality for men and women. Moreover, the increased clarity brought about by such a standard would be beneficial to both potential perpetrators and potential victims. Finally, Part II will argue that a clear and effective consent standard and its accompanying protection of sexual autonomy need not be purchased at a cost to intimacy in sexual relations.

"Feminist activists and theorists agree that a prerequisite for securing a woman's selfhood is assurance of her physical security against male aggression." ${ }^{20}$ A new consent standard based upon affirmative verbal consent would be a step toward assuring such security.

[T] he consent standard could be viewed as a means to afford women their deserved freedom to engage in sex however they choose ... . The harm of rape, or part of it, is the denial of that freedom. Indeed, a consent standard that allowed the individual woman to say "yes" as well as "no," to define all the limits of permissible sex for herself and then to have that definition incorporated and respected in law, would be a means of empowering women. ${ }^{21}$

It is with this goal in mind that this Comment was written.

\section{The Gap Between Current Rape LaW and a Rape Law BASED ON AFFIRMATIVE VERBAL CONSENT}

In essence, most statutory definitions of rape ${ }^{22}$ prohibit sexual

${ }^{20}$ Beverly Balos \& Mary L. Fellows, Guilty of the Crime of Trust: Nonstranger Rape, 75 MINN. L. REV. 599, 599 (1991).

21 Estrich, supra note 8, at 1132.

22 "Rape" and "sexual assault" are the two most common statutory terms. Other labels include: "sexual battery" (Florida), "sexual abuse" (Iowa), "sexual intercourse without consent" (Montana), "criminal sexual penetration" (New Mexico), "gross sexual imposition" (North Dakota) and "criminal sexual conduct" (South Carolina, Michigan, and Minnesota). See Searles \& Berger, supra note 17, at 31.

As prominent feminist and rape law commentator Susan Estrich points out, "[b]y renaming 'rape,' reformers have sought to rid the crime of its common law baggage of unique rules ... of resistance and proof." Estrich, supra note 8, at 1148. As will be seen, analogizing rape law to the law of assault and battery, as the term "sexual assault" suggests, can have extremely positive consequences in terms of bringing women's rights under rape law into conformity with rights afforded to victims of 
activity with another person by force and without that person's consent. ${ }^{23}$ The prima facie case for rape is therefore comprised of four basic elements: sexual activity between the defendant and the victim, use of force or threat of force by the defendant as a means of obtaining that sexual activity, nonconsent of the victim, and mens rea. ${ }^{24}$ The last element, mens rea, is seldom addressed in written opinions or at trial. At least one court has even gone so far as to suggest that there is no mens rea for rape. ${ }^{25}$ Also, some states do not include victim nonconsent as an element of the prima facie case, preferring instead to incorporate victim consent as a defense. ${ }^{26}$ Even under these statutory schemes, however, once a

other crimes. See infra notes 78-81 and accompanying text. This Comment, however, will use the term "rape" because its author agrees with Estrich's further point that "[h]owever well-intentioned, these [label] changes risk obscuring the unique meaning and understanding of the indignity and harm of 'rape." Estrich, supra note 8, at 1148.

${ }^{23} \mathrm{See}$, e.g., MD. ANN. CODE art. 27, § 463(a)(1) (1992) ("A person is guilty of rape in the second degree if the person engages in vaginal intercourse with another person: (1) By force or threat of force against the will and without the consent of the other person ...."); N.C. GEN. STAT. \$ 14-27.3(a)(1) (1986) ("A person is guilty of rape in the second degree if the person engages in vaginal intercourse with another person: (1) By force and against the will of the other person . ..."); VA. CODE ANN. $\$ 18.2-61(\mathrm{~A})(\mathrm{i})$ (Michie 1988) ("If any person has sexual intercourse with a complaining witness who is not his or her spouse ... and such act is accomplished against the complaining witness's will, by force, threat, or intimidation of or against the complaining witness or another person ... he or she shall be guilty of rape."). For an overview of rape statutes in all fifty states and the District of Columbia, see generally Searles \& Berger, supra note 17.

24 See Dana Berliner, Note, Rethinking the Reasonable Belief Defense to Rape, 100 YALE L.J. 2687, 2689-91 (1991) (listing and briefly describing the four elements of rape). For a thorough discussion of the elements of rape and their origins in the common law, see generally Estrich, supra note 8, at 1094-1132.

${ }^{25}$ See Estrich, supra note 8, at 1097, 1098 n.22.

${ }^{26}$ See Berliner, supra note 24 , at 2693 n.43. Under these statutes, the prima facie case is defined solely in terms of the defendant's forceful conduct rather than also including the victim's nonconsent. For example, "[t]he key to the Michigan statute is "force or coercion' by the actor." Estrich, supra note 8, at 1148. See MICH. CoMP. LAWS ANN. \$§ 750.520a -520l(West 1991) ("Sexual penetration" constitutes "criminal sexual conduct in the first degree" where "[t]he actor causes personal injury to the victim and force or coercion is used to accomplish sexual penetration."); see also N.J. STAT. ANN. § 2c:14-1 to 8 (West 1982 \& Supp. 1992) (defining "sexual assault" as "an act of sexual penetration with another person" accomplished by "physical force or coercion"); 18 PA. CONS. STAT. \$ 3121(1)-(2) (1990) ("A person commits a felony of the first degree when he engages in sexual intercourse with another person not his spouse: 1) by forcible compulsion; 2) by threat of forcible compulsion that would prevent resistance by a person of reasonable resolution ...."). This approach is intended to help take the focus of the rape trial off the victim and place it onto the alleged perpetrator. For a thorough argument in favor of this tactic, see Cynthia $A$. Wicktom, Note, Focusing on the Offender's Forceful Conduct: A Proposal for the Redefinition of Rape Laws, 56 GEO. WASH. L. REV. 399 (1988). 
consent defense is raised, the burden devolves upon the prosecution to prove nonconsent. ${ }^{27}$ In effect therefore, a prosecution for rape requires proof beyond a reasonable doubt of sexual activity, force, and nonconsent. ${ }^{28}$

Of these three elements, only force and nonconsent are relevant here. Although varying definitions of the sexual activity element are a significant determinant of the scope of protection different rape statutes afford, none of the possible variations is inconsistent with the adoption of a consent standard based on affirmative verbal consent. ${ }^{29}$ The current nonconsent and force elements, on the other hand, both present an obstacle to the effectuation of such a standard. Section A will therefore argue for 1) a change in judicial interpretation of the nonconsent element and 2) elimination of the statutory requirement that force be proved in addition to nonconsent. Both legislative and interpretive methods of executing these changes will be proposed.

Analysis of the fourth and final element of the prima facie case, mens rea, will be deferred until after a discussion of possible defenses to a charge of rape. The two most commonly asserted defenses in cases of nontraditional rape are consent and reasonable belief in consent (also called mistake of fact as to consent). ${ }^{30}$ As suggested above, the consent defense is merely an attempt by the defendant to show that the prosecution has not met its burden of proving victim nonconsent. When asserting the reasonable belief in consent defense, the defendant argues that he reasonably

${ }^{27}$ See Berliner, supra note 24 , at 2693 n.43.

${ }^{28}$ This is true in every state except Washington, where the burden of proving a consent defense rests with the defendant. See id. (citing State v. Camara, 781 P.2d 483,487 (1989)).

${ }^{29}$ Although the issue of the proper definition of the sexual activity element is outside the scope of this Comment's argument, a quick description of the current status of this element helps to provide a complete picture of current rape law. As part of rape reform, many states have expanded their statutory definitions of rape to include not only penile-vaginal intercourse but a wider range of activities such as "oral, anal, or vaginal penetration by, or union with, the sexual organ of another or the anal or vaginal penetration of another by any other object." FLA. STAT. ANN. $\S 794.011(1)(h)$ (West 1992). Still, as of 1987 , rape remained limited to vaginal penetration in 16 states and the District of Columbia. See Searles \& Berger, supra note 17, at 31. Twenty-four states limited their rape or sexual assault statutes to penetration but included oral and anal penetration as well as vaginal penetration, and 10 states' statutes criminalized both nonconsensual penetration and other types of nonconsensual touching. See id.

${ }^{30}$ See Berliner, supra note 24, at 2693. 
believed the alleged victim had consented to the sexual activity in question. $^{31}$ Because both defenses are often based on inferences from a woman's nonverbal behavior, they are inconsistent with a rape law founded on verbal consent. Section $B$ will therefore argue for the rejection of the consent and reasonable belief in consent defenses as they are currently understood. An alternative consent defense consistent with a norm of affirmative verbal consent will be proposed. Finally, section $\mathrm{C}$ will address the mens rea element and argue that a verbal consent standard comports with well-accepted theories of criminal culpability.

\section{A. The Prima Facie Case}

\section{The Nonconsent Element}

In every state but one, the prosecution's failure to prove victim nonconsent will result in an acquittal. ${ }^{32}$ The law thus creates what is in effect a legal presumption of female consent to sexual activity. Standing alone, such a presumption is inoffensive; it can be viewed as merely effectuating the constitutional guarantee of a presumption of innocence and reflecting the fact that the majority of sexual interaction is consensual. It is the combination of this presumption with judicial interpretation of the nonconsent element that is problematic. Judges have historically held that the burden of proving nonconsent is not satisfied by a showing of a lack of affirmative consent; instead, affirmative nonconsent must be proven. ${ }^{33}$

${ }^{31}$ Note that the defendant is not necessarily arguing that the alleged victim actually consented, but only that he reasonably believed she did. See Steven B. Katz, Expectation and Desire in the Law of Forcible Rape, 26 SAN DIEGO L. REV. 21, 21-22 (1989) ("When a man reasonably expects that sexual access is forthcoming from a woman, he will not be convicted of rape if he proceeds to have sex with her, even though she has not consented to have sex."); see also Sakthi Murthy, Comment, Rejecting Unreasonable Sexual Expectations: Limits on Using a Rape Victim's Sexual History to Show the Defendant's Mistaken Belief in Consent, 79 CAL. L. REv. 541, 548 (1991) (" $[T]$ he defense of mistake of fact regarding the victim's consent asserts that even if the victim did not consent, the defendant thought she did and thus lacked the intent to have sexual intercourse with a nonconsenting woman."). The reasonable belief in consent defense is intended to eliminate the possibility that "defendants who actually believed that the victim was consenting would be convicted for rape." Dettmar, supra note 12 , at 481 . For a thorough discussion of the origins and implications of the standard, see $i d$. at $478-82$.

${ }_{32}$ See supra note 28 and accompanying text.

${ }^{33}$ See Berliner, supra note 24, at 2689 ("To establish 'without consent,' [the prosecution] must prove actual refusal; mere absence of consent or silence will usually be insufficient for conviction."). This is so even under statutes which do not use the 
Although there are other crimes for which nonconsent is an element or consent is a defense, ${ }^{34}$ only in rape is proof of a lack of consent insufficient to prove nonconsent. A common defense to a charge of auto theft, for example, is that the car's owner consented to the defendant's use of the vehicle. A mere showing that the owner never gave the defendant permission to take the car is enough to defeat this defense; no showing that the owner actually told the defendant not to take the car is necessary. ${ }^{35}$ In rape law, however, the "default" position is consent. Proof of the absence of affirmative indications of consent by the victim is not enough to defeat a consent defense; instead, the prosecution must show that the alleged victim indicated to the defendant through her overt actions and/or words that she did not wish to participate in sexual activity with him. Thus, "[ $t]$ he law presumes that one will not give away that which is his to a robber, but makes no similar presumption as to the conduct of women and rapists." 36 In fact, quite the opposite is true: in the context of sexual activity the law presumes consent. For example, proving both that a woman did not verbally consent and that her actions consisted of lying still and not moving does not raise a presumption of nonconsent, but of consent. Only through evidence of some sort of overt behavior such as a verbal "no" or an attempt to push away the defendant can the prosecution meet its burden of proving nonconsent.

Interpreted in this way, the law's presumption of female consent leads to the treatment of sexual encounters as contractual events in which the absence of some "vigorous act of refusal"37 by the woman is considered sufficient proof of her consent. Consequently, a woman's right to control sexual access to her body is not absolute,

term "nonconsent" but instead require that the sexual activity be "without consent," see, e.g., MD. ANN. CODE art. $27, \S 463$ (a) (1991), a standard which, linguistically at least, would seem to be satisfied by a showing of a lack of consent. As will be discussed, however, not all states define or interpret the nonconsent element in this way. See infra notes 51-54 and accompanying text.

${ }^{34}$ See Estrich, supra note 8, at 1121 ("Nonconsent has traditionally been a required element in the definition of a number of crimes, including theft, assault and battery.").

${ }^{35}$ See id. at 1126 ("In robbery, o]nly where the owner of the property actively participates in planning and committing the theft will consent be found. Mere 'passive submission' or 'passive assent' does not amount to consent-except in the law of rape.").

${ }^{96}$ Susan Schwartz, An Argument for the Elimination of the Resistance Requirement from the Definition of Forcible Rape, 16 LOY. L.A. L. REV. 567, 588 (1983).

${ }^{37}$ Pineau, supra note 12, at 233. For further discussion of the "contractual" model of sexual encounters, see generally Katz, supra note 31 . 
but attaches only upon her affirmative assertion of a desire to deny that access on a given occasion. By contrast, the law governing other offenses for which nonconsent is an element (or consent is a defense) places the burden upon the person who would intrude upon a protected right to obtain a waiver of it-permission to borrow a car, consent to perform an operation, or authorization to cross private land, for example. A man wishing to participate in sexual activity with a woman, however, has no obligation to obtain affirmative indications of her willingness to engage in such activity. In the absence of evidence to the contrary, he may presume consent. Only under the law of rape, therefore, the person whose rights may potentially be violated is burdened with the obligation of conveying her nonconsent affirmatively. If she does not do so, she will be unable to vindicate her right to control sexual access to her body. Judicial interpretation of the nonconsent element in this way is one of the causes of the criminal justice system's inability to protect women from rape: "[i]n a culture where incidences of sexual assault are verging on epidemic, a [rape law] which regards mere submission as consent fails to offer persons vulnerable to those assaults adequate protection." 38

Requiring a woman to do anything at all as a prerequisite to protection under the rape laws implies that her freedom from nonconsensual sex is a privilege rather than a right. Furthermore, it suggests that a woman who fails to take such actions has caused her own rape. These same ideas underlie the concept of "[j]ustifiable rape... [which] says that women are inferior under the law and disposable objects if they do something to provoke their attack$\mathrm{er}^{\text {"39 }}$ or, as in this case, fail to do something to discourage their attacker. By requiring women to exhibit their nonconsent affirmatively, current rape law lends credence to this doctrine. If the notion that rape can be justifiable is ever to be dispelled and adequate protection from rape is ever to be provided, the law must declare that proof of a lack of consent satisfies the nonconsent element.

Aside from the inherent unfairness of requiring a person to take affirmative action to protect her rights and the additional unfairness of disparate treatment of rape victims as compared to victims of

${ }^{38}$ Pineau, supra note 12, at 219.

${ }^{39}$ Susan Swartz, Let's Go Over It One More Time: Rape is a Crime, L.A. DAILY J., Oct. 20, 1989, at 6 . For a more complete explanation of this theory, called "victim precipitation," see infra notes $98-101$ and accompanying text. 
other crimes, refusing to treat a lack of consent as nonconsent raises yet another problem. By requiring affirmative manifestations of nonconsent, courts have essentially kept the resistance requirement $^{40}$ alive despite its widespread statutory repeal. ${ }^{41}$ "[T]he utmost resistance standard required that a woman risk serious injury to establish her lack of consent. Thus, rape victims were confronted with the Hobson's choice of risking death or serious harm by resisting or chancing unsuccessful prosecution as a consequence of having submitted to their attackers. ${ }^{n 2}$ Today, verbal resistance will sometimes be sufficient to satisfy the requirement of affirmative nonconsent, ${ }^{43}$ but even this lesser showing is more than is demanded of other crime victims. In many states, moreover, even a showing of verbal resistance is not sufficient proof of nonconsent; instead, "the definition of nonconsent requires victims of rape, unlike victims of any other crime, to demonstrate their 'wishes' [i.e. their nonconsent] through physical resistance. ${ }^{44}$ As a result, victim resistance is maintained as a "ghost element of rape ${ }^{45}$ - $[$ a]lthough no longer explicitly required, it nevertheless remains an unacknowledged yardstick for courts when evaluating evidence of force and consent. ${ }^{n 6}$ Eliminating the resistance requirement has been one of the major accomplishments of rape law reformers. ${ }^{47}$ It should not now be permitted to reappear through a back door opened by an affirmative nonconsent requirement.

${ }^{10}$ Under the common law resistance requirement, in order to satisfy the force element, the victim had to prove that she resisted "to the utmost." Vivian Berger, Man's Trial Woman's Tribulation: Rape Cases in the Courtroom, 77 CoLUM. L. REv. 1, 8 (1977). In some states, such resistance was a statutory requirement. See id.

${ }^{41}$ See Berliner, supra note 24, at 2692 ("The majority of states have repealed the statutory requirement of physical resistance .... .").

42 Dettmar, supra note 12 , at 480 .

${ }^{43}$ In the twenty states which criminalize either nonconsensual penetration, nonconsensual touching, or both without requiring a showing of force, verbal nonconsent would presumably be sufficient to satisfy the nonconsent element of the prima facie case. See Searles \& Berger, supra note 17, at 32, Table 3.

${ }^{44}$ Estrich, supra note 8, at 1122.

45 Berliner, supra note 24, at 2691.

${ }^{46} I d$. at 2692 . Perpetuation of the resistance requirement is not solely a result of courts' interpretations of nonconsent to require something more than mere lack of consent. It is also a result of the fact that force is a separate element of rape which must be proven in addition to nonconsent. This aspect of rape law will be discussed in the next section. See infra notes 55-82 and accompanying text.

47 See Berliner, supra note 24, at 2692 ("Elimination of the physical resistance requirement has been one of the most important goals of rape law reform, and, at least in terms of statutory reform, this goal has largely been achieved."). 
So far, this section has pointed out that proof of a lack of consent is not currently interpreted as sufficient to satisfy the nonconsent element of the prima facie case for rape. It then argued that this interpretation of an otherwise innocuous presumption of consent produces several undesirable consequences: inadequate protection of women, inequitable treatment of rape victims, implied acceptance of the justifiable rape concept, and regressive reinstitution of the resistance requirement. A step toward avoiding these consequences might be to place the burden of proving consent on the defendant, as the state of Washington does, ${ }^{48}$ thereby eliminating the presumption of consent altogether and replacing it with a presumption of nonconsent. On its face, a presumption of nonconsent suggests that a person wishing to engage in sexual activity with another has a duty to ascertain that person's consent or willingness to participate before proceeding. The implicit imposition of such a duty comports with the distribution of responsibility under other laws requiring consent and with the idea that a woman should not be compelled to take affirmative action to protect her right to deny sexual access to her body. As was emphasized above, however, what is problematic is not that the burden of proof of nonconsent rests with the prosecution, but rather the way that burden has been interpreted by the judiciary. Shifting to the defense the burden of proving nonconsent would not reverse the consequences described above so long as courts continued to treat lack of nonconsent as equivalent to consent. Therefore, in order to correct these failures, the law must adopt the opposite position-that proof of a lack of consent is sufficient to prove nonconsent.

One method of accomplishing this change is statutory revision. Such revision would entail including a definition of consent in all rape statutes, as few states currently do, ${ }^{49}$ and defining consent in terms of affirmative signs of willingness to participate in sexual activity. ${ }^{50}$ Wisconsin, for example, defines consent as "words or

${ }^{48}$ See supra note 28.

49 See Berliner, supra note 24, at 2689. An explicit statutory definition is a good idea for several reasons. See Barbara Fromm, Sexual Battery: Mixed-Signal Legislation Reveals Need for Further Reform, 18 FLA. ST. U. L. REv. 579, 595 (1991) ("Omitting a statutory definition of consent gives rise to the possibility that a court will rely on implied consent if there is not adequate proof of force or coercion."); Schwartz, supra note 36, at 593 ("A clear definition of consent . . . must be provided for in a forcible rape statute designed to eliminate the resistance requirement.").

${ }_{50}$ Whereas this section argues that the law should only recognize affirmative signs of consent and should presume nonconsent in all other cases, Section $\mathrm{C}$ will argue that the law of rape should only recognize verbal consent, thus supplying the second 
overt actions ... . indicating a freely given agreement to have sexual intercourse or sexual contact. ${ }^{n 1}$ Similarly, according to Washington's rape statute, “'[c]onsent' means that at the time of the act of sexual intercourse there are actual words or conduct indicating freely given agreement to have sexual intercourse. ${ }^{52}$ A statute modeled on these examples would ensure that courts interpreted the prosecution's proof of a lack of consent as sufficient to establish "without consent" or nonconsent. Such a statute would also ensure that the defendant's proof of an absence of nonconsent would no longer constitute sufficient support for a consent defense.

Politically difficult statutory reform is not the only available solution to the problems caused by the current interpretation of the nonconsent element. In the absence of a statutory definition explicitly requiring overt indications of consent, a court could still find that its state's legislature intended for a lack of consent to constitute sufficient proof of nonconsent. Relatively recent statutory revision in most states $^{53}$ arguably indicates implicit legislative acceptance of the underlying goals of rape reform, and these goals prescribe such an interpretation of the nonconsent element. The New Jersey Supreme Court took just this approach in a recent case, holding as follows:

In redefining rape law as sexual assault, the New Jersey Legislature adopted the concept of sexual assault as a crime against the bodily integrity of the victim. Although it is possible to imagine a set of rules in which persons must demonstrate affirmatively that sexual contact is unwanted or not permitted, such a regime would be inconsistent with modern principles of personal autonomy. The Legislature recast the law of rape as sexual assault to bring that area of law in line with the expectation of privacy and bodily control that long has characterized most of our private and public law. ${ }^{54}$

Whether by statutory reform or policy-guided judicial interpretation, the expectations of privacy and bodily control referred to in the New Jersey Supreme Court's opinion should be honored in the rape law of every state through a clear statement that proof of a lack of consent is sufficient to establish nonconsent. The resulting

half of the affirmative verbal consent standard.

51 WIS. STAT. ANN. § 940.225(4) (West Supp. 1992).

52 WASH. REV. CODE ANN. § 9A.44.010(7) (West Supp. 1992).

${ }^{53}$ See Searles \& Berger, supra note 17, at 25 ('Since the mid-1970's most states have modified or reformed their rape laws.").

${ }^{54}$ State ex rel. M.T.S., 609 A.2d 1266, 1277 (N.J. 1992). 
requirement that consent be exhibited affirmatively or overtly is the first ingredient of the suggested affirmative verbal consent standard.

\section{The Force Element}

Under most rape statutes, proof of sexual activity and nonconsent alone will not sustain a rape conviction..$^{55}$ Force must be shown in addition to these two elements. Thus, "sexual activity without the consent of a woman may not be considered rape if the defendant did not exercise force. ${ }^{56}$ In fact, not only would such behavior not be considered rape, it would probably not be considered criminal at all: the majority of states provide no criminal sanction whatsoever for nonconsensual sexual activity without force. ${ }^{57}$ Suppose, for example, a trier of fact in a rape case were to find beyond a reasonable doubt that the defendant engaged in sexual activity with the complainant in spite of her unequivocal verbal indications that she did not want to engage in sexual activity with him. This finding alone, without proof of the defendant's use of force, could not support a rape conviction nor, in most states, any other conviction. In order to effectuate a "no means no" standard in the law of rape, therefore, the force requirement must be eliminated.

A recent Pennsylvania case, Commonwealth $v$. Berkowitz, ${ }^{58}$ provides a perfect example of the implications of a separate and indispensable force requirement. Pennsylvania statute defines rape as "sexual intercourse with another person . . . by forcible compulsion [or] by threat of forcible compulsion that would prevent resistance by a person of reasonable resolution." ${ }^{59}$ In Berkowitz, the facts were undisputed insofar as both parties agreed that

${ }^{55}$ As mentioned above, nonconsent is not an element of rape in some states. See supra note 26 and accompanying text. However, the prosecution bears the burden of proving nonconsent should the defendant raise a defense of consent. As was also mentioned above, consent is one of the most commonly raised defenses in cases of nontraditional rape. See supra note 30 and accompanying text. In effect, therefore, and especially in cases of nontraditional rape, the prosecution must often prove both force and nonconsent, even where nonconsent is not an element of the crime.

${ }^{56}$ Berliner, supra note 24 , at 2689 n.11.

57 As of 1987 , only eight states criminalized nonconsensual penetration alone. They are Alabama, Iowa, Mississippi, Nevada, Vermont, Washington, Wisconsin and Utah. See Searles \& Berger, supra note 17, at 32, Table 3. Curiously, an additional twelve states criminalized nonconsensual touching but not nonconsensual penetration. See id.

58609 A.2d 1338 (Pa. Super. 1992).

5918 PA. CoNS. STAT. ANN. § 3121 (Supp.1992). 
"throughout the encounter, the victim repeatedly and continually said 'no."'60 The court also found, however, that "[e]ven in the light most favorable to the Commonwealth, the victim's testimony as to the physical aspects of the encounter cannot serve as a basis to prove "forcible compulsion." not satisfied the force element, its case was insufficient to support a conviction for rape under Pennsylvania law, and the defendant was discharged as to that offense. ${ }^{62}$

As with the rule that lack of consent is not sufficient to prove nonconsent, failing to criminally sanction nonforceful instances of nonconsensual sex means that a woman's right to control sexual access to her body is not absolute. The separate force requirement of rape law limits her exercise of that right to situations where her "partner" exhibits force or the threat of force. Since proof of sexual activity combined with a woman's verbal nonconsent, or even her lack of verbal consent, are intended to be dispositive under the redefinition of the consent standard suggested by this Comment, this section will argue for the elimination of force as a necessary element of the crime of rape. The justification for this approach is made clear by another comparison to the law of theft. Although a theft accomplished by force is a more serious offense than a theft accomplished without the use of force, the law does not require an

${ }^{60}$ Berkowitz, 609 A.2d at 1347 (footnote omitted).

$61 \mathrm{Id}$.

${ }^{62}$ See id. at 1352 . In some states, the complainant has an alternative criminal remedy. Twenty states criminalize nonconsensual touching without requiring proof of forcible compulsion. See Searles \& Berger, supra note 17, at 32, table 3. Twelve states, including Pennsylvania, punish nonconsensual touching alone, and an additional 8 states criminalize either nonconsensual penetration or both nonconsensual penetration and nonconsensual touching. See id.

In many of these states, however, pursuing a complaint for nonconsensual touching is not an entirely satisfactory remedy. Pennsylvania law, for example, classifies rape as a first degree felony but "indecent assault" as merely a misdemeanor. See 18 PA. Cons. STAT. ANN. \$§ 3121, 3126 (Supp. 1992). Under such a law, a defendant like the one in Berkowitz could be convicted only of the same crime as someone who, for example, touched a woman's breast without her consent, see id. at $\S 3126$, despite the fact that he subjected the complainant to nonconsensual intercourse. This possibility illustrates the need for statutes graded in terms of both the degree of force employed and the type of sexual contact involved.

Moreover, 30 states and the District of Columbia have statutes which criminalize neither nonconsensual penetration nor nonconsensual touching in the absence of force, thereby leaving complainants in cases such as Berkowitz with no remedy under the criminal law. See Searles \& Berger, supra note 17, at 32, table 3. A recent decision by the New Jersey Supreme Court suggests, however, that even a statute with a separate force requirement can be interpreted to allow for a remedy under nonforceful circumstances. See infra notes $72-81$ and accompanying text. 
acquittal in a case where force cannot be proved. The current law of rape in most states, on the other hand, would require an acquittal in such a situation.

Aside from the fact that with other crimes an absence of force leads not to the defendant's acquittal but rather to finding him guilty of a lesser crime or perhaps sentencing him to a lesser punishment, there is another reason why absence of force should not make the difference between guilt and innocence: absence of force or threat of force may provide no indication of the defendant's willingness or readiness to use force. Rather, it may simply be a reflection of the fact that no force was required in order to overcome the victim. If a woman is inordinately afraid, too embarrassed to defend herself, or simply indisposed to resist in any situation $^{63}$ she may submit to nonconsensual sex even in the absence of a display of force or threat of force by the defendant. Under a standard that calls for acquittal under nonforceful circumstances, the easily subdued or intimidated potential victims ${ }^{64}$-those arguably most in need of protection-receive no protection at all.

One method of overcoming rape law's failure to criminalize nonconsensual sex alone is to create a lesser included offense for which force or threat of force is not a requirement, as some states have. ${ }^{65}$ In Vermont, for example, "[a] person who engages in a sexual act with another person and compels the other person to participate in a sexual act without the consent of the other person ${ }^{n 6}$ is guilty of sexual assault. In Iowa, a "sex act" constitutes sexual abuse in the third degree when " $[t]$ he act is done by force or

${ }^{63}$ Surprisingly, especially in acquaintance rape situations, women frequently fail to resist or call out for help because they are too embarrassed to do so or are afraid of being rude to their rapist or hurting his feelings. See WARSHAW, supra note 18, at 5 (recounting one woman's experience).

${ }^{64}$ A significant number of women might fall into this category. Feminists argue that a "definition of consent that equates consent with nonresistance . . . is oblivious to the greater social and physical power of men. In the face of this inequality, women may not resist unfair inducements to male sexual initiatives, yet at the same time may not welcome those initiatives." Martha Chamallas, Consent, Equality, and the Legal Control of Sexual Conduct, 61 S. CAL. L. REv. 777, 814 (1988).

${ }^{65}$ An important caveat is that the lesser included offense should not be so much "lesser" that it fails to indicate the seriousness of the offense. This was the failing of the Berkowitz case in Pennsylvania. See supra notes 63-66 and accompanying text.

${ }^{66}$ VT. STAT. ANN. tit. 13, § 3252 (Supp. 1992). Searles \& Berger list Vermont as a state which criminalizes nonconsensual penetration. See Searles \& Berger, supra note 17 , at 32 , table 3 . Presumably, therefore, the word "compels" in the statutory definition requires no showing of force. 
against the will of the other participant. ${ }^{n 67}$ The codification in all states of lesser included offenses such as these would significantly increase the scope of protection offered by many current statutory schemes.

As with the lack of nonconsent equals consent problem, however, a judicial solution is also available. A recent New Jersey Supreme Court decision, State ex rel. M.T.S., ${ }^{68}$ involved New Jersey's sexual assault statute, which criminalizes "sexual penetration using physical force or coercion. ${ }^{n 69}$ The record disclosed that the defendant had "engaged in actual sexual penetration of the girl [the complainant] to which she had not consented. There was no evidence or suggestion that the [defendant] used any unusual or extra force or threats to accomplish the act of penetration. ${ }^{n 70}$ On these facts, the trial court held that the physical force requirement had been satisfied solely by proof of the nonconsensual sexual penetration of the alleged victim. ${ }^{71}$ The appellate court reversed on the ground that the statute required "some level of force more than that necessary to accomplish penetration. ${ }^{72}$ The supreme court agreed with the trial court, holding that "physical force in excess of that inherent in the act of sexual penetration is not required for such penetration to be unlawful" and that the physical force element would be satisfied "if the defendant applies any amount of force against another person in the absence of what a reasonable person would believe to be affirmative and freely-given permission to the act of sexual penetration. ${ }^{73}$

The decision was based in part on an analogy to assault and battery standards because the court felt that the legislature had exhibited a desire to "redefine rape consistent with the law of assault and battery." ${ }^{74}$ The court explained that under that body of law, the terms "physical force" or "coercion" are not separate elements but are simply intended to characterize all contacts that are unwanted by or offensive to their recipient. Reasoning by analogy, the court concluded that sexual penetration is criminal "when 'physical force' or 'coercion' demonstrates that it is unautho-

\footnotetext{
${ }^{67}$ IOWA CoDE ANN. $§ 709.4$ (West Supp. 1992).

${ }^{68} 609$ A.2d 1266 (N.J. 1992).

${ }^{69} I d$. at 1267 (describing the New Jersey statute).

${ }^{70} \mathrm{Id}$.

${ }^{71}$ See id.

72 Id.

73 Id. at 1277.

74 Id. at 1276.
} 
rized and offensive. Thus, just as any unauthorized touching is a crime under the traditional laws of assault and battery, . . . so is any unauthorized sexual penetration a crime under the reformed law of sexual assault." ${ }^{\text {75 }}$ The court also based its decision on the legislature's intent to eliminate the requirements of resistance and affirmative nonconsent, saying that "to require physical force in addition to that entailed in an act of involuntary or unwanted sexual penetration would be fundamentally inconsistent with [that] legislative purpose. ${ }^{76}$ Essentially, without actually eliminating the force element, the court made it possible for a complainant to prove sexual assault without a separate showing of force. It thus rejected the law's "injection of a concept of 'force' over and above the coercion implicit in denying sexual freedom of choice. ${ }^{\text {77 }}$ Instead, the force inherent in the nonconsensual sexual activity was considered sufficient. Because it operates within a statutory scheme with a separate force element, the New Jersey court's opinion represents an excellent model for expanding rape law's protection of women in states that do not statutorily criminalize nonconsensual sexual activity alone.

This section has shown that because of statutory language, judicial interpretation, or both, the prima facie elements of the crime of rape fail to add up to a legal scheme which can adequately protect a woman's right to control sexual access to her body. Because proof of a lack of consent is insufficient to prove nonconsent, women may vindicate their right to control sexual access to their bodies only if they take affirmative action to protect that right. This is more than is required of victims of any other crime. Because force is a separate and indispensable element of rape in many jurisdictions, women have no legal remedy against nonconsensual sex alone. To correct these problems, two measures must be undertaken. First, only overt behavior should be construed as consent; a lack of consent therefore must be interpreted to indicate nonconsent. Second, force should not be considered an indispensable element of rape but rather an aggravating factor, determining the degree of the crime perpetrated and/or the severity of the punishment imposed. Alternatively, the amount of force necessary

${ }^{75} I d$.

${ }^{76} I d$. As noted before, many states' rape reform statutes explicitly reject the resistance requirement. See supra note 47 and accompanying text. This legislative intent argument would thus be available to many state courts.

77 See Berger, supra note 40 , at 8. 
to accomplish the sexual contact in question should be considered sufficient to establish the statutory force element. ${ }^{78}$ Both of these measures have already been adopted in some jurisdictions, either statutorily or judicially. If women's right to sexual autonomy is to be absolute-the goal of the affirmative verbal consent standardthese measures must be adopted universally.

\section{B. The Defenses}

By exposing injustices inherent in the current formulations of the prima facie elements of rape, section $A$ showed that a rape law that truly recognized a woman's right to sexual autonomy would 1) interpret a lack of consent as nonconsent, thus no longer requiring overt manifestations of unwillingness to participate in sexual activity as support for the element of nonconsent, and 2) eliminate force as a necessary element of rape. This section will argue for the final element of the standard suggested in the Introduction-a requirement that consent be stated verbally.

The problem with the defenses of consent and reasonable belief in consent ("the consent defenses") is that, like the elements of the prima facie case, they limit a woman's right to control sexual access to her body. The last section demonstrated that inferences of consent drawn from a woman's inaction unjustly require her to take affirmative action to protect her right to sexual autonomy. Conversely, this section will argue that the consent defenses, by drawing inferences of consent from certain actions of a woman, unjustly require her to refrain from those actions in order to protect her right to sexual autonomy. The problem of unjust inferences from a woman's actions or inaction could be resolved by a standard mandating that the only legally recognizable signals of consent are verbal statements. Indeed, it is for the purpose of solving this problem that such a standard is suggested here. Standing alone, however, a verbal consent standard would be overinclusive because sexual activity might be consensual despite a woman's failure to indicate her consent verbally. Therefore, the suggested standard includes an affirmative defense, through which a man would be given the opportunity to prove that his partner consented to the sexual activity in question even though explicit verbal consent was never given.

${ }^{78}$ In this case, differentiation between cases involving varying degrees of force would occur at the sentencing stage. 
Because no jurisdiction currently limits its interpretation or definition of consent to verbal consent only, proof of either words or actions indicating a willingness to participate in sexual activity may be used to establish a consent defense. As a result, a woman's consent may be, and often is, inferred from her nonverbal behavior and actions. In fact, an inference of consent may arise even in the face of verbal indications of nonconsent. ${ }^{79}$ The consent defenses thus place the force of law behind the common social practice of inferring consent from behavior other than a woman's explicit verbal agreement to engage in sexual intercourse. ${ }^{80}$ Consequently, women who wish to maintain the legal right to exercise control over sexual access to their bodies must refrain from exhibiting behavior that men and the legal system may take to signify consent.

Requiring such restraint as a condition of legal protection from rape would not be problematic if there were a nearly perfect correlation between behaviors intended by women to indicate consent and behaviors from which men and the legal system inferred consent. In that case, women would simply refrain from consent-indicating behaviors in all cases except those in which they actually wished to signal consent to sexual activity. The problem is that no such correlation exists. Rather, the set of behaviors considered to be indicative of consent is grossly overbroad, including many actions that very well might not denote consent on a given occasion. Current rape law thus presents a woman with the choice of either refraining from all of the many behaviors the law

${ }^{79}$ For a recent example, see Commonwealth v. Berkowitz, 609 A.2d 1338 (Pa. Super. Ct. 1992). In Berkowilz, it was undisputed that "throughout the encounter, the victim" repeatedly and continually said 'no." Id. at 1347. Nevertheless, the court held that it was reversible error to exclude evidence of the fact that "her boyfriend and she had argued over the question of her fidelity" because such evidence "suggested that the victim may have sought to explain away an imprudent act of consensual intercourse." Id. at 1351 (emphasis added). Clearly the court believed that the jury could have made a finding of consent even in the face of undisputed evidence that the complainant verbally indicated her nonconsent. "The insistence that men are entitled not only to presume consent from silence but actually to ignore a woman's explicit words makes all too clear the law's absolute determination not to empower women at all." Estrich, supra note 8, at 1132.

${ }_{80}$ See Antonia Abbey, Misperception as an Antecedent of Acquaintance Rape: A Consequence of Ambiguity in Communication Between Women and Men, in ACQUAINTANCE RAPE: The HIDDEN CrIme 96, 97 (Andrea Parrot \& Laurie Bechhofer eds., 1991) ("Most Americans feel uncomfortable discussing sexual intentions and desires, particularly if they think their sexual interest may not be reciprocated. Consequently, people try to infer sexual intent from indirect verbal and nonverbal cues rather than through frank discussion."). 
or men might consider indicative of consent, or relinquishing her right to protection of her sexual autonomy.

As some examples will illustrate, there is essentially no limit to the type of behaviors jurors have considered indicative of a woman's consent. The current consent defenses allow factfinders to give legal effect to these interpretations, either by finding that the prosecution has not met its burden of proving nonconsent beyond a reasonable doubt, or by finding that the defendant acted reasonably in interpreting the complainant's behavior as consent. Consider the following:

In 1989, a circuit court jury in Florida acquitted [a] 26-year-old [defendant] of abducting a 22-year-old woman at knife point and repeatedly raping her. The jury based its finding partly on the fact that she was wearing a lace miniskirt without underwear. In explaining the decision of the three-man, three-woman jury, foreman Roy Diamond said: "We felt she asked for it for the way she was dressed." 81

This incident shows that even in the case of a violent stranger rape the legal system may deny a woman who exhibits certain behavior (in this case, dressing provocatively) the ability to vindicate her right not to be raped. It is true that the verdict may have been more a result of the jury's opinion that the complainant deserved to be raped than of an actual finding of consent as defined by Florida's law. Nevertheless, the failing of Florida's legal definition of rape is that it does not preclude opinions such as those of the jurors in this case from being given the force of law. ${ }^{82}$ Under a standard based on affirmative verbal consent, on the other hand, this type of outcome would be unquestionably precluded by statute or precedent and would thus be extremely unlikely.

The example just cited was one of traditional, violent stranger rape. In the case of nontraditional rapes, juries may consider an even broader range of behavior in support of a consent defense. ${ }^{83}$

81 Nemeth et al., supra note 4, at 42, 44.

82 Florida's rape statute has since been changed "to preclude the admissibility in a prosecution for sexual battery of 'evidence presented for the purpose of showing that [the] manner of dress of the victim at the time of the offense incited the sexual battery." Fromm, supra note 49, at 580 (quoting FLA. STAT. ch. 90-40, § 794.022(3) (1990)).

83 See Balos \& Fellows, supra note 20, at 601 ("Current law allows defendants to use a preexisting relationship to give credibility to a defense of consent or reasonable, good faith belief of consent."). As one commentator lamented, a woman may be viewed as consenting to intercourse just by letting a man she knows into her house: 
[I]f a woman previously consented to any connection with a mandeveloping a friendship with a male colleague or superior at work, accepting a date, going to a bar or a party and talking with a man (i.e. making a stranger a nonstranger through conversation), agreeing to drive a man she has just met to his home, allowing a man she just met to drive her home, dating a man for an extended period of time, consenting to sexual relations with a man once or many times, cohabitating with a man, marrying a man-a presumption arises that she subsequently consented to sexual contact during the incident in question. ${ }^{84}$

Other behaviors and qualities that may be used as a proxy for consent in both the stranger and nonstranger rape contexts include promiscuity, flirting, good looks or bad looks, and race. ${ }^{85}$ Thus, factfinders consider both sexual and nonsexual characteristics. "A woman who sends out signals, such as drinking, dancing or hitchhiking, is assumed to have invited the rape. A victim's 'provocative clothing' or 'sexually promiscuous' behavior are also signals of 'implied' consent," 86 as is sexual activity short of intercourse. Jurors may infer consent from a victim's failure to fight her attacker or her failure to report the assault to the police promptly. ${ }^{87}$ Because " $\left.t\right]$ he assumption that a sexually experienced woman is more likely to consent remains in our legal system to-

Allowing a male friend into your home who turns violent and rapes you cannot be prosecuted in court. In the eyes of the court, allowing the male into your home implies consent for him to have sexual intercourse with you. The courts apparently see that opening your front door to a man means that the vagina is opened to his penis.

SUSAN Griffin, RAPE: THE Polmtics of Consciousness 72 (1986) (quoting Kathy Barry in Stop Rape [pamphlet]). Barry reminds her readers that "[a]s brash and boorish as these conclusions may sound, we must understand that they constitute the thinking of society and the courts, not of women." Id.

${ }^{84}$ Balos \& Fellows, supra note 20, at 604-05.

${ }^{85}$ See Wicktom, supra note 26 , at $406,409$.

${ }^{86}$ Tchen, supra note 12, at 1524 (footnote omitted); see also Wicktom, supra note 26, at 408 ("Social activities, such as drinking, dancing, and dating, have been interpreted as indications that the victim consented to the alleged rape."); Amy DePaul, The Rape Trauma Syndrome: New Weapon for Prosecutors, NAT'L L.]., Oct. 28, 1985, at 1,1 (citing a study of 331 jurors involved in 38 sexual assault trials in Indianapolis between 1978-1980 conducted by sociologists from the University of New Mexico, the University of Illinois, and the National Academy of Sciences' National Research Council, which found that drinking, drug abuse, and extramarital sexual activity can cause jurors to doubt a woman's story).

${ }^{87}$ See DePaul, supra note 90, at 1 . As DePaul points out, far from indicating that the alleged assault was in fact a consensual sexual encounter, these behaviors may in fact be "immediate psychological effects of trauma" accompanying a rape experience. Id. 
day, ${ }^{n 88}$ women who use oral contraceptives and women with live-in boyfriends are less likely to be believed when they claim they did not consent to the sexual activity at issue. ${ }^{89}$

The question the factfinder in a rape trial purports to answer is this: did the complainant consent to a particular sexual activity, with a particular man, on a particular occasion? As even a cursory examination will show, the above laundry list of behaviors includes many that provide scant, if any, assistance in answering this question. First of all, many of the behaviors have other meanings wholly unrelated to sex. A woman may drink for purposes of celebration; she may take oral contraceptives for health reasons; she may dress provocatively because it makes her feel confident. ${ }^{90}$ Secondly, if these behaviors do have a meaning related to consent to sexual activity, that meaning may pertain to one particular man only, or at least not to the alleged rapist. For example, a woman may dress provocatively in order to be sexually attractive to her boyfriend, or she may take oral contraceptives so that she and her partner can have sexual intercourse without fear of pregnancy. Each of these behaviors is related to sexual activity with one specific man, yet any man who introduced such information in court might receive the benefit of jury misperception of such behaviors as indicia of consent. Third and finally, behaviors which are meant to indicate consent to sexual activity on one particular occasion may not be meant to indicate consent on another. For example, sexual behavior short of intercourse may be intended as a prelude to intercourse on some occasions and an end in itself on others. Similarly, consent to intercourse in the past is not necessarily indicative of consent to intercourse on a later occasion.

Thus, there may be slight or no correlation between actual consent and behavior from which a jury deduces consent. In fact, studies corroborate that " [s] uch deductive strategies [in determining consent to sexual activity] are bound to produce frequent er-

${ }^{88}$ Murthy, supra note 31, at 550.

${ }^{89}$ See DePaul, supra note 90, at 1 (also stating that "recent jury research has confirmed . . . that jurors in rape cases in which consent is an issue-especially when the victim is young, unmarried and sexually active-are often predisposed to believe the defendant's claim that 'she wanted it').

${ }^{90}$ See Abbey, supra note 84 , at 100 ("Frequently people wear revealing clothing to attract the attention of a potential sexual partner. Given our society's emphasis on physical attractiveness, however, some people may dress in such a way simply to look their best, for the sake of their own self-esteem, and not to attract sexual partners."). 
rors." 91 Given the high likelihood of error and the gravity of the harm caused by such errois (i.e., unpunishable rapes), the perpetuation of a legal standard based on nonverbal consent is unconscionable. Because current law does not tell jurors that the only fact relevant to a finding of consent is whether or not the woman verbally consented, however, the jury remains free to consider a broad range of irrelevant female behavior in making its consent determinations. Just as interpretation of the consent element in the prima facie case requires women to act affirmatively to exhibit their nonconsent, the consent defenses require women not to act in certain ways because men are liable mistakenly to interpret those behaviors as consent, and factfinders are likely legally to sanction those mistakes through one of the consent defenses. Thus, "the burden of sexual misunderstandings ultimately resides with the female and the consequence is a categorical denial of self-determination. ${ }^{\text {"92 }}$ Women must either refrain from participating in these activities or assume the risk of nonconsensual intercourse. In direct contradiction to the goal of increasing female autonomy, this aspect of rape law places strict bounds on female behavior.

A verbal standard, by contrast, accords with the principle of maximum autonomy for women. A requirement of verbal consent at the time of sexual activity would result in a near-perfect correlation between legal and actual indications of consent: there could be no question that the behavior is intended to be an indication of consent to sexual activity; the intended recipient of the signal would be clear; and finally, no inference could be drawn from irrelevant consent to sexual encounters on other occasions. Under such a standard, the only "behavior" from which a woman would be required to refrain in order to preserve her right to legal protection of her sexual autonomy would be an entirely reasonable one-verbal indication of consent at the time of sexual activity.

As has just been shown, factfinders' ability to consider an overbroad range of female behaviors in support of the consent defenses means that women must restrict their behavior lest failure to do so should leave them the victims of unpunishable rapes. ${ }^{93}$ In this respect, current rape law comes unconscionably close to

91 Id. at 97.

92 Eugene J. Kanin, Date Rape: Unofficial Criminals and Victims, 9 VIcTimology 95, 103 (1984).

${ }^{93}$ For a concise, forceful condemnation of this implication of current rape law, see Swartz, supra note 39, at 6 . 
giving legal effect to victim precipitation theories, which posit that certain behaviors of women provoke or lead to rape. ${ }^{94}$ These theories are especially detrimental to the victims of nontraditional rape who are of central concern to this Comment. According to the victim precipitation model, when a woman has placed herself in a situation that might result in sexual activity (a prerequisite which, as we have seen, may be interpreted very broadly), "she must accept the consequences of her own conduct (i.e. nonconsensual sexual contact). Of course, the law does not explicitly state that a presumption arises, nor does it explicitly rely on the assumption of risk argument." I5 In fact, however, juries' application of the consent defenses is often indistinguishable from application of the victim precipitation theory. "[T]he range of supposedly contributory behavior extends from a casual discussion with a stranger at a party, to the unwary practice of hitchhiking, to an evening spent with a boyfriend. Expectations of victim precipitation color jury deliberation on nonconsent, causing the jurors to focus on the complainant's behavior ...."96

As with the prima facie elements, an analogy to the law of theft illustrates the inequity of this approach:

It is one thing ... to say that such persons were terribly careless and quite another to state categorically: "When a woman drinks with a man to the point of intoxication, she practically invites him to take advantage of her person. She should not be permitted to yell when she is sober, 'I was raped!' A man who flashes a roll of hundred dollar bills is also probably courting trouble, yet no one suggests that he cannot later cry, "I was robbed!"97

94 See Wicktom, supra note 26, at 408-09 \& nn.64-65.

95 Balos \& Fellows, supra note 20, at 605. Not quite so subtle as "the law," Mike Tyson's lawyer actually argued that because of Tyson's known propensity for violence, "that to date him was to consent to sex." Tyson Takes the Count, NATION, Mar. 2, 1992, at 253. In their famous study of the American jury, Kalven and Zeisel called such arguments, and the victim precipitation theory in general, $a$ "bootlegging of the tort concepts of contributory negligence and assumption of risk' into the working law of rape." HARRY KALVEN \& HANS ZEISEL, THE AMERICAN JURY 242-45 (1966), quoted in Berger, supra note 40 , at 30 .

${ }_{96}$ Harris, supra note 12 , at $624-25$ (footnote omitted).

97 Berger, supra note 40, at 26 (quoting MORRIS PLOSCOWE, SEX AND THE LAW 175 (1951)). One prosecutor put it this way in his closing argument at a rape trial: "Any woman has the right to say no .... . You wouldn't let a burglar go free because the door was not locked. Don't let a rapist go free because a [woman] is too dumb not to make herself an easy mark." GARY D. LAFREE, RAPE AND CRIMINAL JUSTICE: THE SOCIAI CONSTRUCTION OF SEXUAL ASSAULT 175 (1989) (quoting the prosecutor in an actual rape case). Both defendants were acquitted on all counts. See id. at 176; see 
Unlike the current consent defenses, a standard based on verbal behavior would emphasize that no matter what a woman does before or after a sexual encounter, the relevant question is whether or not she said "yes" during it. Such a law would treat alleged rape victims in the same way as alleged victims of other crimes, rather than leaving them no legal recourse when they act in "rape precipitative" ways.

Thus far, this Comment has argued for a rape law based on a standard of affirmative verbal consent. This is not to say, however, that affirmative verbal consent is to be the only legally relevant form of consent. Such a standard would be overinclusive because it would not account for the possibility that even in the absence of verbal consent, a sexual encounter might in fact be consensual. Under these circumstances, no rape has occurred..$^{98}$ In order to

also Harris, supra note 12, at 625-26 ("Evidence rules and instructions which encourage the jury to indulge its notions of victim precipitation fail to protect a woman's freedom of sexual choice.").

${ }_{98}$ Although a rape has not occurred, a man acts at least negligently and perhaps recklessly or purposely when he fails to avail himself of the most unambiguous form of consent-verbal consent. Morally, a man is culpable for failing to obtain verbal consent whether his partner implicitly consented or not: the fact that his partner implicitly consented is more a matter of luck than a reflection of his intentions. Her implicit consent does not change the fact that by pursuing continued sexual activity before obtaining verbal consent, he risked subjecting her to unwanted sex acts.

On a "no harm, no foul" theory, however, this Comment takes the pcsition that criminal punishment would not be appropriate in such cases. Instead, sinifting the burden of proof of consent to the defendant and setting the standard of proof at beyond a reasonable doubt is sufficient deterrent to or punishment for his failure to obtain verbal consent.

Another possible reason for criminalization in all cases where verbal consent is lacking, including those in which the jury makes a finding of consent, is to provide a safety net for women who have been raped but are unable to convince a jury of their nonconsent. Such women would at least be able to have their rapist convicted of a lesser offense solely on the basis of his failure to obtain verbal consent. This offense might be called "sexual endangerment" and would essentially be a strict liability offense based on proof of sexual activity in the absence of verbal consent. Criminalizing sexual endangerment is a desirable alternative in a society where juries will still acquit a rapist because his victim "asked for it" by wearing a short skirt. See supra text accompanying note 85 .

On the other hand, a sexual endangerment offense has the potential to backfire on women. Under a gender-neutral statute, a man who subjects his partner to nonconsensual sex might be able to claim that she had failed to obtain his verbal consent. This could happen, for example, in a rape situation in which neither actor spoke. Without the opportunity to avoid conviction by proving the man's actual consent through evidence of his actions, the woman would be found guilty of sexual endangerment: she participated in sexual activity without obtaining her partner's consent. A desire to avoid this result is a second reason not to criminalize sexual activity in the absence of verbal consent without regard to actual consent. The 
preclude conviction in such cases, the following approach is suggested. The prosecution's case would consist of proof of: 1) sexual activity, and 2) verbal nonconsent or absence of verbal consent. Proof of verbal nonconsent would raise an irrebuttable presumption of nonconsent ( $a$ "no" means "no" standard). Proof of the absence of affirmative verbal consent would raise a rebuttable presumption of nonconsent; the burden of proof would then shift to the defendant to show through evidence of nonverbal signals that the complainant had actually consented to the sexual activity in question despite her lack of verbal consent. Actual consent would have to be proved beyond a reasonable doubt.

It might be argued that affording the defendant an opportunity to prove that actual consent was present despite the absence of verbal consent undermines all the advantages of a verbal standard and reintroduces the liberty-restricting practice of inferring consent from a woman's behavior. This argument, however, underestimates the impact of shifting the burden of proof beyond a reasonable doubt to the defendant. Because under the current law of rape the burden of proving nonconsent remains with the prosecution at all times, the defense has only to raise a reasonable doubt in the jurors' minds as to the victim's nonconsent. One piece of evidence, for example that the complainant was wearing provocative clothing, might be sufficient to do just that. The proposed standard, however, would require the defendant to prove beyond a reasonable doubt that the complainant had consented to sexual activity on a particular occasion. Given that there are several other reasons why a woman might wear provocative clothing (i.e., to attract a man other than the defendant, for her own self-esteem, because she wanted the defendant to ask her out on another date), this same evidence that could easily raise a reasonable doubt as to nonconsent would be much less likely to convince the jury beyond a reasonable doubt of the complainant's consent. Thus, the shifting of the burden severely limits the usefulness of behavioral evidence, which in turn limits its negative impact on women's freedom. ${ }^{99}$ Further-

proposed standard avoids this pitfall by providing an affirmative defense of consent. Thus, should a man file a charge against a woman for failure to obtain his verbal consent when he in fact raped her, she could avoid conviction by proving beyond a reasonable doubt that his actions (e.g., sustaining an erection, ejaculating, etc.) indicated consent.

${ }_{99}$ Moreover, other aspects of the proposed consent standard would operate to limit the ability of the defendant to use behaviors such as those listed above to imply consent. A definition of consent based on overt acts at the time of intercourse like 
more, placing the burden on the defendant comports with the distribution of responsibility characteristic of other laws for which nonconsent is an element or consent is a defense: it suggests that a man has a duty to ascertain his partner's consent before proceeding with sexual activity. The implicit imposition of such a duty is an improvement over current law, which suggests just the opposite, namely, that a woman has a duty to convey her nonconsent if she wishes to retain her right to deny sexual access to her body.

\section{Mens Rea and Culpability}

Focusing on the prima facie case, section $A$ argued for elimination of the separate force requirement and adoption of a standard based on affirmative manifestations of consent. Moving to a discussion of defenses, section $B$ argued that unless such manifestations of consent are verbal, the defendant should bear the burden of proving consent beyond a reasonable doubt. Together, sections $A$ and $B$ construct a consent standard based on affirmative verbal consent. This section will explain why men who fail to adhere to the suggested standard should be considered criminally culpable. In so doing, it addresses the mens rea for the nonconsent element, ${ }^{100}$ an issue which was bypassed in section A's discussion of the prima facie case.

As was mentioned earlier, courts often ignore the mens rea element entirely. ${ }^{101}$

To refuse to inquire into mens rea leaves two possibilities: turning rape into a strict liability offense where, absent consent, the man is guilty of rape regardless of whether he (or anyone) would have recognized nonconsent under the circumstances; or defining the crime of rape in a fashion that is so limited that it would be virtually impossible for any man to be convicted where he was truly unaware or mistaken as to consent. ${ }^{102}$

that suggested above would render many such behaviors irrelevant. More stringent evidentiary restrictions could also be used to prevent a consent defense based on nonverbal conduct from overwhelming the advances accomplished by a prima facie case based on nonverbal conduct. A discussion of the many possibilities of this approach, however, is beyond the scope of this Comment.

100 As to the mens rea for the sexual activity element, the proposed standard would be satisfied by a showing that the accused recklessly, knowingly, or intentionally engaged in the sexual activity in question.

101 See supra note 25 and accompanying text.

${ }^{102}$ Estrich, supra note 8, at 1098. 
The first possibility convicts men who many would not consider morally culpable, while the second provides women with inadequate protection from rape. In order to avoid these pitfalls, the suggested standard establishes the mens rea for rape at negligence.

In states which recognize a reasonable belief in consent defense, the mens rea threshold for rape is negligence; unreasonable mistakes are punished while reasonable mistakes are not. ${ }^{103}$ The suggested standard can be viewed as maintaining this mens rea threshold, but declaring per se unreasonable all mistakes caused by a failure to obtain verbal consent. The reasonable belief in consent defense would thus be limited to those cases in which a mistake as to actual consent was made in spite of verbal consent. In other words, if the woman says "yes" but really means "no," a man will not be punished for his inability to read her mind; reliance on her verbal "yes" would be considered reasonable behavior. ${ }^{104}$ Other than in such a situation, a defendant's only consent-related defense would be actual consent, under which he would be acquitted only when the factfinder found beyond a reasonable doubt that consent (albeit nonverbal) was actually given and therefore that no rape occurred.

As mentioned above, when a defendant raises a reasonable belief in consent defense, he is not arguing that nonconsensual sex did not occur. ${ }^{105}$ Rather, he is arguing that his belief in consent, although erroneous, was "reasonable." 106 Thus, as a result of the

${ }^{103}$ Some states excuse for unreasonable mistakes as well. For a discussion of different states' treatment of the mistake as to consent defense, as well as the English approach, see generally, Dettmar, supra note 12, at 483-91.

${ }^{104}$ It might be argued that such a standard could be thwarted by simply forcing or frightening a woman into saying "yes." Keep in mind, however, that the suggested definition of consent requires that consent be "freely given." See generally supra notes 51-52 and accompanying text. This requirement guards against the possibility of a man using force or coercion to obtain an exculpatory "yes."

On the other hand, a woman who says "yes" for reasons other than force or coercion such as subtle persuasion, her belief that it will cause her partner to love her, or her desire to attain some other goal would not receive legal protection under this definition. In this sense, the definition of rape suggested here is narrower than that of some prominent feminists.

Another possible avenue for an acquittal under the suggested reasonable belief in consent defense would be if the woman made a verbal statement which she understood to indicate nonconsent, but which was interpreted by her partner as consent. In this case, the jury would have to decide whether the defendant's misinterpretation was "reasonable." For example, a mistake resulting from impaired judgment caused by alcohol consumption might be (and in the author's opinion should be) considered unreasonable.

105 See supra note 31 and accompanying text.

106 In states which excuse even for unreasonable mistakes, the defendant argues 
availability of this defense, it is possible that an incident would not be punished as a rape in spite of legal recognition that a woman has been subjected to nonconsensual sex. A realm of "reasonable rape" is created in which women must bear the risk of men's mistakes.

Defenses which exculpate despite legal recognition that a victim's rights have been violated are obviously not unique to the rape context. Such defenses represent a moral decision that the violated interest is outweighed by other interests and that punishment is therefore morally inappropriate. For example, a defendant who kills because she reasonably believes her life is in danger will not be convicted of murder even if she was in fact wrong in her belief. Her acquittal represents society's moral decision not to punish because the harm of punishing a person who merely responded to a reasonable and natural desire to preserve her life would be even greater than the harm of a purposeful killing.

In recognition that the striking of such balances is necessary and desirable, this Comment does not argue for a change in the reasonable belief in consent defense solely on the ground that its availability results in some instances of nonconsensual sex going unpunished. Rather, it argues that the law strikes an improper balance between the harm that occurs when a woman is subjected to nonconsensual sex and the harm that occurs when a man is punished for a mistake that society considers reasonable: too many culpable men are never punished, and too many violated women are unable to vindicate their rights. The reason for this imbalance, and therefore the reason why the reasonable belief in consent defense results in "too many" acquittals, is that the current definition of "reasonable" fails to recognize the ease with which mistakes as to consent may be avoided by means of a verbal inquiry. The suggested standard restores a proper equilibrium by refusing to excuse mistakes caused by a failure to obtain verbal consent. Instead, it dictates that "[i]f the circumstances result in an ambiguity, sexual activity should not occur unless and until that ambiguity is positively clarified and consent is certain." 107 Thus, in addition to declaring reliance on nonverbal consent per se unreasonable, the suggested standard can also be viewed as placing upon men an affirmative duty of inquiry. In the absence of verbal consent, men would have a duty to inquire as to their partner's willingness to

that his mistake as to consent was "honest." See generally Dettmar, supra note 12 , at 482-89.

${ }^{107}$ Balos \& Fellows, supra note 20, at 617. 
participate before proceeding with sexual activity. A man who has not established the willing participation of his partner by obtaining her verbal consent must bear the risk of punishment should it turn out that she was not in fact consenting. Thus, protection of a woman's sexual autonomy is declared more important than protection of a man's freedom not to trouble himself with inquiring as to his partner's consent. This section will attempt to justify such a stance.

One factor weighing in favor of a decision to excuse mistakes under the criminal law is that the person making the mistake was not responsible for creating the situation in which the mistake was made. For example, "a person acting in self-defense may not have exercised any choice in finding himself or herself in the predicament in which the mistake is made. ${ }^{.108}$ In cases where the actor is responsible for creating the predicament in which the mistake occurs, however, the law is much less likely to excuse. The law's failure to excuse self-defense killings in which the defendant created a situation requiring self-defense by provoking her attacker with deadly force exemplifies this principle. Applying these considerations to the man who engages in sexual activity with his partner without her verbal consent reveals that 1 ) he has exercised choice in deciding to participate in a sexual encounter, and 2) he has created the possibility that he may make a mistake by engaging in sexual activity without inquiring as to his partner's consent. ${ }^{109}$ Both of these factors therefore weigh against excusing such a man under a mistake of fact defense. Moreover, whereas a person defending his life may not simply walk away from the situation, "[t]he pursuit of sexual enjoyment can be abandoned without loss to anything other than the satisfaction of hedonistic pleasure."110

This last observation is the root of Jeremy Horder's argument as to when mistakes should be exculpatory. Horder examines the reason a mistake is made, arguing that sexual desire is not a morally

${ }^{108}$ Celia Wells, Swatting the Subjectivist Bug, 1982 CRIM. L. REv. 209, 217.

109 This statement should be distinguished from a claim that the man has singlehandedly created the situation in which his mistake occurs. A woman may also have exercised choice in, for example, accepting an invitation to a man's apartment or engaging in behavior short of legally relevant sexual activity. Such choices, however, are not relevant here. To consider such choices would once again give legal effect to victim precipitation theories and the notion that "she deserved it." Under the proposed standard, the only relevant choice is the choice to proceed with sexual activity in the absence of verbal consent, regardless of which party to the interaction precipitated the events leading up to the actual sexual encounter.

110 Wells, supra note 108, at 214. 
acceptable reason for a mistake as to consent. ${ }^{111}$ Out of this argument he fashions "a moral theory whose focus is the evaluation of actions stemming from desires associated with emotions. "112 The theory compares different emotions behind our actions that lead to mistakes, concluding that some are morally justifiable reasons for mistaken behavior and some are not. Using uncontrolled sexual desire as an example of an emotion responsible for mistakes as to consent, Horder argues that such desire is not "an emotion that creates the kind of imperative for immediate action that understandably and excusably leads people to do wrong, as by leaping before looking properly" or that creates "an imperative for immediate satisfaction that may lead even ethically well-disposed agents understandably and excusably to act wrongly." 113 An example of an emotion that can excuse mistakes under Horder's theory is fear: "great fear, involving inter alia a great desire for safety, gives a priority in practical reasoning to immediate escape from the situation that is regarded by ethically well-disposed agents as in some circumstances excusing negligent wrongdoing." 114

In a potential rape situation, the actor's thoughts are not clouded by fear and an accompanying desire for safety, although they may be clouded by sexual desire and an accompanying yearning for sexual satisfaction. Horder concludes that unlike mistakes caused by fear, mistakes caused by these emotions and desires are not morally justifiable:

Even when the desire for sexual satisfaction is great, we expect, in morality as in law, that desire will be expressed in relation to another only in the context of a fully consensual relationship with that other person. ... [T] he experience of such a desire does not per se provide what ethically well-disposed agents would regard as a sound moral basis for excusing negligent consequent wrongdoing. ${ }^{115}$

To hold otherwise would be to subscribe to the notion that "rape is the result of desires which, once aroused in a man, cannot be controlled and for which women are to blame."116 Rape reformers have struggled to combat this rape myth, under which a man can

111 See Jeremy Horder, Cognition, Emotion, and Criminal Culpability, 106 LAW Q. REV. 469 (1990).

112 Id. at 476 .

113 Id. at 479 .

114 Id. at 477 .

${ }^{115} I d$.

116 Dettmar, supra note 12, at 473. 
scarcely ever be held morally responsible for a rape. Horder's theory also rejects this myth and provides a second reason in support of a duty to obtain verbal consent.

In her article Swatting the Subjectivist Bug, ${ }^{117}$ Celia Wells provides a third reason for such an approach. The primary focus of her argument is to advocate an objective rather than a subjective standard of liability for mistakes as to consent. She argues that the relevant question for assessing the culpability of a rape defendant is not "Did the defendant know the alleged victim was not consenting?" but "Should the defendant have known that the alleged victim was not consenting?" Wells feels that as a baseline matter, a person who has failed to perceive that his or her partner is not consenting is to some degree culpable:

If there is sufficient evidence to satisfy a jury that consent was absent, can it not be argued that this is sufficient to distinguish, in terms of culpability, the mistaken defendant from those men who have never had sexual intercourse with a woman who was not consenting? If the defendant is so out of touch with the reality of the situation, is there not a suggestion that he should take more care to ensure that his sexual partner is willing? Social protection might be better served by the punishment of a defendant who failed to acquaint himself with this (seemingly) elementary fact. ${ }^{118}$

This line of reasoning also supports the imposition of an affirmative duty to obtain verbal consent. A man who fails to obtain his partner's verbal consent and as a result subjects her to nonconsensual intercourse is more culpable than a man who always takes the care to use an easily available and unambiguous means-verbal communication-to make certain that his partner is consenting.

Keeping to well-established standards of criminal liability, Wells applies George Fletcher's question for assessing culpability: "[C]ould the actor have been fairly expected to avoid the act of wrongdoing? Did he or she have a fair opportunity to perceive the risk, to avoid the mistake ... ? ${ }^{n 119}$ The availability of a reliable method of ascertaining consent in the form of a verbal inquiry provides a fair opportunity to avoid the mistake of having sexual contact with a nonconsenting partner. This is a simple task with an

117 See Wells, supra note 108.

118 Id. at 212-13.

119 Id. at 213 (quoting George P. Fletcher, RethinkING Criminal LAW 510 (1978)). 
easily understandable response that places no burden on the actor other than the possibility of a loss of sexual enjoyment if it turns out that his or her partner is not consenting. If a person chooses not to avail himself or herself of this opportunity, he or she cannot be said to be without culpability.

[T] hose who engage in the activities subject to such regulation [sex where there is uncertainty concerning one's partner's consent] take the risk of contravening the standards prescribed. This disposes of the 'blameless innocent' approach but it has to be justified in terms of societal gain. One of those gains would be the reduction of the harm ... against which the regulation is aimed.... Another gain could be societal 'satisfaction' in obtaining obedience to its laws, whatever they may be. In other words, even if criminal sanctions had no effect, there is a societal need to declare that [nonconsensual sex is unacceptable.]

A consent standard based on affirmative verbal consent declares that subjecting women to a risk of nonconsensual sex by relying on unreliable nonverbal signals is unacceptable behavior in our society.

Yet another argument in favor of the imposition of a duty of verbal inquiry is based on a comparison of the magnitude of the harm to be avoided and the difficulty involved in its avoidance. Toni Pickard expressed her opinion on this balance as follows: " $[\mathrm{C}]$ onsidering the disparate weights of the interests involved, a failure to inquire carefully into consent constitutes ... such a lack of minimal concern for the bodily integrity of others that it is good criminal policy to ground liability on it." 121 Thus, Pickard concludes that when the gravity of the harm is so great and the intrusiveness of the safety measure so small, it is morally acceptable to punish an actor who has it within his means to avoid the harm but does not.

In rape, we are dealing not with the kind of mistake that results from the complexity of our endeavours and inevitable human frailty, but with an easily avoided and self-serving mistake produced by the actor's indifference to the separate existence of another. When the harm caused is so great, it seems clear to me

${ }^{120} I d$. at 218 . In this part of her article, Wells is not discussing rape, but the application of strict liability to the sale of unfit food. Her arguments, however, also apply to the decision to declare a failure to ascertain consent per se unreasonable.

121 Toni Pickard, Culpable Mistakes and Rape: Relating Mens Rea to the Crime, 30 U. TORONTO L.J. 75, 77 (1980). 
that making such a mistake is sufficiently culpable to warrant criminal sanction. ${ }^{122}$

This is exactly the theory behind an affirmative verbal consent standard. Failure to obtain verbal consent, the clearest and most unambiguous form of consent, is easily avoided-all a man must do is ask his partner for her consent. His failure to undertake this simple task shows that he selfishly cares more about his immediate satisfaction than the possibility that he might be subjecting another person to nonconsensual sex. Given the ease of avoidance compared to the harm of non-avoidance, his behavior shows a lack of respect for his partner's right to sexual and bodily integrity. Hence, he is a culpable individual.

Finally, imposing an affirmative duty of inquiry as to consent may be seen to comport with general principles of criminal liability laid out in Joel Feinberg's book Harm to Others. ${ }^{123}$ Feinberg examines criminal culpability by comparing the liberty interest of the actors involved. He explains that "[a] particular legal statute may impose a duty on everyone (say) not to assault John Doe, and in virtue of that general duty, Doe's liberty (to come and go as he wishes) is strengthened. Protecting him in the exercise of his liberty is the point of limiting everyone else's in this respect."124 In the case of rape, the point of limiting men's liberty by requiring them to obtain verbal consent is to increase a woman's freedom to behave however she wishes without waiving her right to protection under the rape laws. This may include, for example, dressing or acting provocatively or engaging in sexual activity short of intercourse. The proposed redefinition of rape represents a declaration that a woman's interest in sexual autonomy is greater than a man's interest in engaging in sexual activity without having to bother to inquire as to consent. One justification for this determination might be that engaging in sexual activity without verbal consent is a selfish act.

Now a selfish act, whatever else it may be, is one that is morally defective. A person acts selfishly when he pursues his own interests (or the satisfaction of transitory desires and appetites) wrongly at the expense of others. . . An act is selfish only when its pursuit of self-interest is somehow in excess of what is right or reasonable in the situation. ${ }^{125}$

122 Id. at 83.

123 JOEL FEINBERG, HARM TO OTHERS (1984).

124 Id. at 8.

125 Id. at 76 . 
As Horder and Wells both argue, the pursuit of sexual satisfaction at the expense of possibly subjecting one's partner to nonconsensual sex is "in excess of what is right or reasonable in the situation." 126 Thus, punishment of those who fail to obtain verbal consent from their partners can be viewed as condemnation of a selfish act.

Imposing a duty to inquire as to consent before participating in potentially nonconsensual intercourse comports with the distribution of responsibility characteristic of other criminal offenses, which never excuse the defendant because of his or her victim's failure to prevent the crime. Why in rape should the burden be on the potential victim to prevent harm from coming to herself rather than upon the potential perpetrator to refrain from harming another? In contrast to the liberty-infringing ramifications of requiring potential victims to express their nonconsent (behavioral restrictions and legally unrecognized victimization), it can hardly be said that an affirmative duty of inquiry unduly restricts freedom. From the standpoint of the potential perpetrator,

[t]he inquiry he must undertake is simple: a single fact has been isolated and declared legally relevant to the doing of a single, temporally and spatially finite, intentional act. Consent is a matter of present fact, not of potential future consequences. There are only two legally relevant possibilities: consent is given or it is not. There is a discrete method, available to virtually everyone, of clarifying any ambiguities: actual verbal inquiry. And the one person who possesses the necessary information is, after all, right there. ${ }^{127}$

Given the harm to be avoided, it seems a small price to require this simple inquiry. ${ }^{128}$

\section{A STANDARD BASED ON VERBAL CONSENT}

Part I examined those aspects of current rape law which would have to be changed if a consent standard based on affirmative verbal consent were to be promulgated. Each change was justified in accordance with the goals behind rape law and criminal law in general. Finally, the discussion explained why a man's failure to

${ }^{126} I d$.

127 Pickard, supra note 125, at 81 (footnotes omitted).

${ }^{128}$ As one pair of commentators put it, "[g]iven the severity of the harm and pain that rape victims experience, the obligation positively to inquire so that unequivocal consent is obtained seems a minimal requirement indeed." Balos \& Fellows, supra note 20 , at 618 . 
obtain verbal consent should be considered a culpable action. This Part will explain how the standard constructed in Part I would solve two of the major problems of current rape law: first, that it does not draw a clear line between consensual sexual encounters and rape, and second, that rather than insisting upon sexual autonomy for women, it merely reflects and perpetuates the sexually coercive nature of our society. This Part will also explain why the solution of these problems need not be accompanied by a loss of intimacy in sexual relations.

Section A will elucidate the advantages of a bright line standard in a confusing area-namely that it puts potential perpetrators on notice and informs potential victims of their rights. Section $B$ will demonstrate that the proposed standard is preferable to current law because it prescribes proper respect for female sexual autonomy rather than simply mirroring our sexually coercive society. Finally, Section $\mathrm{C}$ will establish that rather than somehow ruining the intimacy of sexual relations, a norm of affirmative verbal consent could actually enhance them.

\section{A. Clarity}

[R]ape statutes are designed to both protect women and convict those persons guilty of the crime. To many, these two objectives seemed irreconcilable. Reflected throughout the legislative and adjudicatory history of rape laws is a fear that the larger goal of protecting women will be achieved at the price of convicting some innocent men. ${ }^{129}$

This fear is exacerbated by current rape law's failure to draw a bright line between consensual sex and rape. ${ }^{130}$ In particular, the lack of a clear demarcation is a source of concern for potential perpetrators because it fails to provide adequate notice of what sorts of behavior are prohibited. The law makes it quite clear that one cannot jump out of the bushes and force a woman to have sex at knifepoint, but where are the lines drawn in more ambiguous cases? Confronted by recent nationwide publicity of nontraditional rape and sexual harassment cases, ${ }^{131}$ and an increased judicial willing-

129 Dettmar, supra note 12, at 474 (footnote omitted).

130 "Though the law attempts to make a clear division between rape and sexual intercourse, in fact the courts find it difficult to distinguish between a case where the decision to copulate was mutual and one where a man forced himself upon his partner." GRIFFIN, supra note 87, at 8.

${ }^{131}$ In the wake of Clarence Thomas's confirmation hearings and William Kennedy Smith's rape trial, a Time magazine article characterized men's fears as follows: "How 
ness at least to consider these cases, ${ }^{132}$ men have grown increasingly frustrated by the lack of a bright-line standard: ${ }^{133}$

I used to be worried about being rejected by women ... . But now I'm worried about losing my job or going to jail if I make the wrong move. I don't know what the rules are anymore. ${ }^{134}$

As a straight white man, I've probably committed date rape, seeing as it's now defined so loosely as to include a peck on the cheek that's not explicitly demanded. ${ }^{135}$

As these statements illustrate, the "still-murky legal terrain of date rape ${ }^{\$ 136}$ makes many men feel "especially vulnerable to charges of sexual misconduct" and "confused about the rules and about what women want (and don't want) in social situations." ${ }^{\text {137 }}$ Indeed there are many "accused men-shocked, defiant or simply bewildered-who deny that they are rapists or insist that their accusers engaged willingly in sex. ${ }^{138}$ Seemingly random lines between consensual sex and rape merely fuel men's fears of fabricated or vindictive charges brought by the "victim" after a consensual encounter. ${ }^{139}$ As with any legally proscribed behavior,

are men to know what the rules are when they appear to be ever changing? At what point does misunderstanding become a crime? If the charges prove false, how does a man retrieve his good name?" Nancy Gibbs, Relationship of the Year: Man and Woman, TIME, Jan. 6, 1992, at 47.

132 For example, two 1992 cases discussed earlier addressed allegations of nonconsensual sex involving little or no force by the defendant. See Commonwealth v. Berkowitz, 609 A.2d 1338 (Pa. 1992) (acquittal); State ex rel. M.T.S., 609 A.2d 1266 (N.J. 1992) (conviction).

${ }^{133}$ One commentator asserts that

women's growing militancy on the issue of date rape . . . has alarmed many men. "The political momentum has swung to the other side of the gender gap," ... "We live in a time of sexual inquisition." Other men express fears that a misunderstood gesture or a vengeful woman could land them in court.

Nemeth et al., supra note 4, at 43 (quoting a February 1992 PLAYBOY magazine article).

134 Baber, supra note 1 , at 36.

135 Richard Blow, Mea Culpa, The New RePublic, Feb. 18, 1991, at 32; see also Nemeth et al., supra note 4 , at 45 (quoting a man's comment that "[t]he way things are going, every man who has sex today is committing a crime-its getting out of hand").

${ }^{136}$ Marci McDonald, Beyond the Trial, MacLEaN's, Dec. 23, 1991, at 16, 17.

${ }^{137}$ Baber, supra note 1 , at 36.

${ }^{138}$ Carl Mollins, His Word or Hers: Celebrity Rape Cases Put Violence Against Women

On Trial and Raise New Fences Between the Sexes, MAcLeAN's, Feb. 17, 1992, at 40, 41.

${ }^{139}$ See Nemeth et al., supra note 4, at 43 (quoting an anonymous 27 -year old male high school teacher from Toronto who claimed that "Some women are almost 
when potential perpetrators are not given adequate notice of what sorts of conduct are prohibited, the resulting fear that innocent men will be thrown in jail leaves decisionmakers reluctant to return convictions and undermines public confidence in the law.

A legitimate and effective criminal law, therefore, should make the division between criminal and noncriminal conduct clear so that potential perpetrators may conduct themselves accordingly and designated decisionmakers may render their verdicts with a clear conscience. Much of the confusion about the line between consensual sex and rape is caused by the fact that "[o]n the continuum of sexual conduct, rape is still a crime that is defined by 'legal language' rather than by an acknowledgement that 'no means no." 140 The proposed standard avoids this problem, making it perfectly clear what sorts of behavior are acceptable and unacceptable: a freely-given "yes" means "yes," and "no" means "no." Those who do not adhere to these guidelines are guilty of rape. The standard is easily understood and easily followed because it so clearly delineates a norm of acceptable behavior. As a result, convictions no longer seem random and unjust and public confidence in the validity of the law is restored.

Potential victims as well as potential perpetrators would benefit from the shift to a clearer standard. Studies show that women are still often reluctant to label a nonconsensual sexual experience "rape" if it occurs under nontraditional circumstances. ${ }^{141}$ This leads some people, and especially those accused or convicted of

gunning for you").

140 Fromm, supra note 49, at 596-97.

141 See WARSHAW, supra note 18, at 3 ("[S]tudy after study has shown that women who are raped by men they know often don't even identify their experiences as rape."). In her study of date rape, psychology professor Mary Koss found that "73\% of the women forced into sex avoided using the term rape to describe their experiences, and only $5 \%$ reported the incident to police." John Leo, When the Date Turns Into Rape, TiME, Mar. 23, 1987, at 77.

Psychologist Barry Burkhart of Auburn University explains this tendency as follows: "Because it is such a paralyzing event, so outside the realm of normal events, [the victims] literally don't know what happened to them." Id. (quoting Barry Burkhart, a psychologist at Auburn University). Warshaw suggests that " $[\mathrm{b}]$ ecause the assault occurs between individuals who know each other, within the context of the often confused personal and sexual relationships between men and women, it's difficult for many people to label it correctly." WARSHAW, supra note 18, at 4; see also Nemeth et al., supra note 4, at 44 (quoting Mary-Ellen Hurman, a Canadian prosecutor who explained that date rape is a difficult crime to prove "because some people, including victims, don't even believe it's rape because rape is portrayed in movies as being a stranger off the street"). 
rape, to ask, "[i]f you have to convince a woman that she has been raped, how meaningful is that conclusion? ${ }^{n 142}$ Others worry that the definition of rape would be extended to include "every female student who has reluctantly given in to her insistent boyfriend and regretted it later. ${ }^{n 143}$ Thus, people are troubled by the idea of criminalizing incidents in which the victim herself has not labeled the experience a rape. For example, one irate commentator had this reaction to the results of a recent Ms. Magazine study:

Nearly three-quarters of the co-ed 'rape victims' in a study sponsored by Ms. magazine did not agree that they had in fact been raped. Fully half of them later engaged in consensual sex with the men who had allegedly 'raped' them.

...

And insofar as the media and the courts take [the underlying studies] seriously, they raise the prospect of people serving long prison sentences for what is really seduction or a breach of sexual etiquette deserving that slap in the face that means 'no' even more effectively than 'no.'144

In the case of rape, the law has only recently begun to recognize many experiences as rapes. "The status of women has been elevated in society. Rape used to be seen as a woman's lot in life. Now it is a violation." 145 Victims have been slow to realize that they are entitled to be free from violations of their sexual wishes in any context. ${ }^{146} \mathrm{~A}$ law that clearly gives them that right is valuable

142 See, e.g., Stephanie Gutmann, Date Rape: Does Anyone Know What it is?, PLAYBOY, Oct. 1990, at 48, 51. In the rape trial of William Kennedy Smith, for example, Judge Mary Lupo refused to admit the testimony of three prosecution witnesses who claimed to have been sexually assaulted by Smith on previous occasions under similar conditions. Commenting on one of the woman's statements, one author wrote, "it was not clear whether she was accusing him of date rape or of being a cad." McDonald, supra note 140, at 18.

${ }^{143}$ Wrong on Rape, THE ECONOMIST, May 18, 1991, at 14.

144 When No Means No, NAT'L REV., June 10, 1991, at 12, 13.

${ }^{145}$ Ric Dolphin, Rape on Campus: Wild Parties and Fears About Walking Alone, MACLEAN's, Oct. 31, 1988, at 56 (quoting Nathan Pollock, a coordinator of clinical psychology at the Clarke Institute of Psychiatry in Toronto).

${ }^{146}$ Some commentators blame this slow awakening on the criminal justice system itself:

Given that police officers, jurors, attorneys, and judges, to name a few, rarely regard forced intercourse between acquaintances as rape, it is hardly surprising that women who have been forced by a male acquaintance to have sexual intercourse against their will, and men who have forced female acquaintances to have sexual intercourse against their will, often do not regard these experiences as rape. 
because, "the laws against physically forced sex will not be effective unless victims also regard such force as unjustified and illegal. ${ }^{1147}$ The proposed standard makes a clear statement that any form of nonconsensual sex, not just physically forced sex, is a violation of the victim's right to sexual autonomy. Under such a standard, the victim, like the potential perpetrator, can easily identify sexual contact that violates her rights because she knows whether or not she gave her verbal consent. A victim's knowledge of her rights is an essential first step toward her vindication of those rights.

Finally, the proposed standard would also help rape victims by increasing the likelihood of prosecution in cases of nontraditional rape. Not surprisingly, prosecutors are currently reluctant to take on and unlikely to win rape cases in this category. ${ }^{148}$ In fact, many reported rapes never even reach this stage because police fail to record them as rapes. ${ }^{149}$ A rape law that clarified the indistinct line between consensual sex and rape by means of a verbal consent standard would send an unmistakable message to society that even those instances of nonconsensual sex characterized by a lack of violence or involving a previous relationship between the defendant and the complainant are deserving of criminal punishment. As

Patricia A. Harney \& Charlene L. Muehlenhard, Rape, in SEXual Coercion: A SOURCEBOOK ON ITS NATURE, CAUSES, AND PREVENTTON 3, 5-6 (Elizabeth Grauerholz \&c Mary A. Koralewski eds., 1991).

${ }_{147}$ Chamallas, supra note 68, at 819. As the 1990 House of Representatives Report discussed, the failure of some women to recognize their experiences as rape prevents not just these women from receiving legal redress, but other rape victims as well.

Another major problem is that most of us, including victims themselves, have an extremely narrow definition of rape. When we think of rape, we tend to think of an adult woman who is brutally attacked by an unsavory total stranger. We don't think about the male rape victims, or the child who is raped by her father, or the woman who is raped by her husband, or the college student who is raped by her boyfriend. We focus on the small fraction of rape cases that come to the attention of the criminal justice system and forget about the vast majority of rape victims for whom the criminal justice system and the services it provides are irrelevant. Without increased attention to these rape victims whose cases do not fit the narrow definition, progress in treatment of rape victims will remain limited to female adult stranger rape cases.

House Hearings, supra note 2, at 41 (statement of Dean G. Kilpatrick, Ph.D., Professor of Clinical Psychology, and Director, The Crime Victims Research and Treatment Center, Medical University of South Carolina, Charleston, S.C.).

148 See McDonald, supra note 140 , at 18 ("Legal experts said that the line is so fine between forced sex and insensitive loutishness that prosecutors seldom bring daterape cases to trial and, if they do, they seldom win.").

${ }^{149}$ See supra note 4. 
mentioned above, this message in the law would likely render juries more likely to convict in such cases. This in turn might lead to decreased police "unfounding" and increased prosecution of rapes.

As this section has shown, the proposed standard is one under which members of the public, potential perpetrators, victims, police, prosecutors and eventually the legal factfinder and decisionmaker can easily distinguish between consensual sex and rape. It thus has the potential to increase the recognition, reporting, prosecution, and conviction of rape. In so doing, it could alleviate the most serious manifestation of current rape law's shortcomings, namely, that most victims' rapists are never punished by the criminal justice system.

\section{B. Prescription Rather Than Description}

Aside from clarity, the suggested standard also carries with it the advantage that it is based upon a vision of equality in sexual interactions. In this respect, it differs from current law, which merely reflects our sexually coercive society and its resulting inequality and miscommunication between men and womer in the sexual arena. ${ }^{150}$ The confusion over the line between nonconsensual sex and rape just discussed, for example, is one result of the current rape law's mirroring of societal flaws. Ultimately, however, such a law leads not just to confusion, but to a perpetuation of sexual inequality between men and women.

Societal ascription of stereotypical male and female sexual roles informs both men's and women's understanding of sexual communication. "Little boys pick up the message that they are supposed to be powerful, not act like a 'sissy,' and compete at all times ...." ${ }^{n 151}$ When these boys become men, they may feel pressured to "conquer a woman sexually" and "not submit to any of her requests." 152 Because their understanding of a sexual interaction

${ }^{150}$ An in-depth examination of sexual coercion in our society or miscommunication between men and women is beyond the scope of this Comment. Instead, the main point of this section is to emphasize that current law perpetuates rather than alleviates such problems.

151 Ann Norton, Talking Back to Sexual Pressure, Whole EARTH ReV., Summer 1992, at 111 (reviewing Elizabeth Powell, TalkIng BaCK to Sexual Pressure (1991)).

${ }^{152}$ Id. These types of messages may be especially strong in all-male groups like fraternities and athletic teams. One study found that approximately half of reported acquaintance rapes nationwide were perpetrated by fraternity members and athletes. See Constance Johnson, When Sex Is the Issue, U.S. NEws \& WORLD REP., Oct. 7, 1991, 
is informed by these assumptions, " $[\mathrm{m}]$ en . . . frequently misinterpret the intent of various dating behaviors and erotic play engaged in by their opposite-sexed partners. ${ }^{\text {153 }}$ Women, on the other hand, may be taught entirely different values. ${ }^{154}$ Despite their actual desire, "decent" women are expected to express reluctance to engage in sexual activity to avoid being labeled a "slut" or "easy," while "real" men, who supposedly always want sex, are expected to overcome women's feigned reluctance and give them what they "really" want. ${ }^{155}$

Thus, both men and women are socialized to accept coercive sexuality as the norm in sexual behavior. In many ways society sends the message that "sexual violence is sexy." 156 As a result, men often see extreme forms of aggressive sexual behavior as seduction, rather than rape. Women too may learn to accept many forms of nonconsensual sex as "normal"; this is part of the reason why so few women label such experiences rape. One result of both sexes' acceptance of this norm of coercive sexual behavior is that women's attempts to limit the extent or nature of sexual contact are not taken seriously. Psychologist Eugene J. Kanin's date rape study revealed that:

In 68 percent of the cases of consensual genital play the female was reported to have stipulated or made an effort to stipulate that this was to be her maximum level of sexual activity .... These delimiting pronouncements were not taken seriously since they were viewed to be the usual show of reticence that respectable

at 94 (citing a 1990 national survey of 12,000 students by the Campus Violence Prevention Center at Towson State University in Maryland). The article cited another study which found that "athletes were reported for raping a student once every 18 days on average and that they were nearly 40 percent more likely to be reported for rape than the average male on campus." Id. (citing a 1986 survey by the Philadelphia Daily News of 200 college police departments and rape counselors). Of the 61 reported rapes involving athletes studied, only seven ended in the prosecution and conviction of the athletes. See id. at $\mathbf{3 6}$. At one college, of the 54 reported sexual assaults by students, 34 were committed by fraternity men, who only made up approximately one-quarter of the male student body. See id. at 34 (citing a 1990 study by the University of Illinois at Urbana-Champaign).

153 Wiener, supra note 12 , at 147.

154 See Norton, supra note 155, at 111 (explaining that women are not taught to "seek success and power," but rather to "value love and relationships," "be nice and loving," and "wait until they are "chosen").

155 Elizabeth R. Allgeier \& Betty J. Turner Royster, New Approaches to Dating and Sexuality, in SEXUAL CoERcion: A SOURCEBOOR ON ITS NATURE, CAUSES, AND PREVENTION, supra note 150, at 133, 140.

${ }^{156}$ Tyson Takes the Count, supra note 99, at 253. 
females demonstrate in order to ward off the impression of being "easy." 157

These findings illustrate how interpretation of sexual communication is often filtered through the belief, fostered by a male-dominated society, that "not only does a woman mean 'yes' when she says 'no,' but that a really decent woman ought to begin by saying 'no,' and then be led down the primrose path to acquiescence," 158 or, as men's rights advocate Ross Virgin put it, "sometimes ['no'] mean[s] maybe, sometimes it means later."'159

Although reliance on frequently misinterpreted nonverbal signals often results in nonconsensual sex, current rape law allows men to continue to rely on such signals rather than insisting that they avail themselves of their clearer verbal counterparts. In fact, current law even allows men to rely on nonverbal signals in the face of conflicting verbal signals; ${ }^{160}$ unambiguous verbal signals take a back seat to nonverbal signals, so that even legally, "no" may mean "yes." The law thus takes a descriptive rather than a prescriptive role. That is, rather than prescribing how sexual relations between equal partners should be characterized, it is content to enforce expectations created by the coercive sexual structure currently in place. Like society as a whole, the law subscribes to a vision of women as the designated objects of male sexual aggression who feign resistance to male advances despite internally welcoming them. Legal acceptance of this image results in a denial of female sexual self-determination. For example, "[a] woman may believe she has communicated her unwillingness to have sex-and other women would agree, thus making it a 'reasonable' female expression. Her male partner might still believe she is willing-and other men would agree with his interpretation, thus making it a 'reasonable' male interpretation." ${ }^{161}$ As a result, many incidents women consider rape are in effect considered "normal' by both male perpetrators and the male-dominated legal system. ${ }^{162}$ When these instances

${ }^{157}$ Kanin, supra note 96 , at 101.

158 GRIFFIN, supra note 87 , at 8 .

${ }^{159}$ Nemeth et al., supra note 4, at 45. Says yet another commentator, "[men] know that depending on context and nonverbal signals, 'No' can mean 'maybe,' 'convince me,' 'back off awhile,' or 'get lost." John Leo, Don't Oversimplify Date Rape, U.S. NEWS \& WORLD REP., Feb. 11, 1991, at 17, 17.

160 See supra note 83 and accompanying text.

161 Wiener, supra note 12 , at 148 (footnote omitted).

162 Id. at 147 (footnote omitted). 
result in acquittal, a man goes unpunished although a woman feels she has been raped.

This discrepancy would be corrected by a law recognizing that a reasonable man, knowing the high likelihood of miscommunication that characterizes nonverbal cues and appreciating the grave harm of subjecting a woman to nonconsensual sex, would avail himself of a less ambiguous expression of consent, that is, verbal consent. Rather than considering the man's behavior unreasonable because he has acted on the basis of signals he knows to be unreliable, however, current law excuses his behavior as "reasonable" because it is normal in our sexually coercive society. The proposed standard based on affirmative verbal consent rejects this approach. By respecting clearly-stated expressions relating to willingness to participate in sexual activity rather than reinterpreting them to fit male visions of sexuality, it promotes female self-determination. It tells women that they have the absolute right to control sexual access to their bodies, thus making clear to them when they have been unfairly victimized. It also sends a clear message to every man that when he has sex with a woman who willingly states her consent, he is not raping her; when he has sex with a woman who has verbally expressed her unwillingness, he is violating her rights, raping her, and breaking the law. If she has expressed neither consent nor nonconsent, he has an obligation to inquire into the situation further before proceeding. As Susan Estrich has observed:

We live ... in a time of changing sexual mores-and we are likely to for some time to come. In such times, the law can cling to the past or help move us into the future. We can continue to enforce the most traditional views of male aggressiveness and female passivity, continue to adhere to the "no means yes" philosophy ... until and unless change overwhelms us. That is not a neutral course, however; in taking it, the law (judges, legislators, or prosecutors) not only reflects (a part of) society, but legitimates and reenforces those views. ${ }^{163}$

By setting out a clear standard for behavior, the proposed standard provides a blueprint for social change, rather than simply enforcing the status quo.

163 Estrich, supra note 8, at 1181. 


\section{Intimacy}

One possible objection to the idea of a mandatory verbal inquiry is that it threatens to destroy the intimacy of sexual relations-that seeking and acquiring verbal consent would "ruin the moment." This objection assumes a sort of "silent is sexy" view of intimate physical relations, "a conception of sexual pleasure that springs from wordless interchanges, and of sexual success that occurs in a place of meaningful silence." 164 This idea is exemplified by Professor Neil Gilbert's concern that under broader "feminist" definitions of rape, "the kaleidoscope of intimate discoursepassion, emotional turmoil, entreaties, flirtation, provocation, demureness-must give way to cool-headed contractual sex: Will you do it, yes or no? Please sign on the line below."165 Despite what television, films, magazines, and novels suggest however, "meaningful silence" is unlikely to lead to sexual pleasure for either party, especially where the silence has different meanings for each (as is frequently the case). ${ }^{166}$ In reality, informed, consensual, pleasurable sexual encounters are the result of communication, not silence; and since verbal messages are the clearest, most unequivocal variety of sexual communication, they are also most likely to lead to desirable sexual encounters.

Another problem with the "silent is sexy" view of intimate encounters is that it shares some of the same underlying assumptions that lead to the notion that women enjoy being raped. As Lois Pineau has pointed out:

the assumption that a raped female experiences sexual pleasure implies that the person who rapes her knows how to cause that pleasure independently of any information she might convey on that point. Since her ongoing protest is inconsistent with requeststo be touched in particular ways, to have more of this and

164 Pineau, supra note 12, at 229.

165 When No Means No, supra note 148, at 13 (quoting Neil Gilbert). Journalist Stephanie Gutmann, "an ardent foe of what she calls the date-rape dogmatists," asks:

How can you make sex completely politically correct and completely safe? ... What a horribly bland, unerotic thing that would be! Sex is, by nature, a risky endeavour, emotionally. And desire is a violent emotion. These people in the date rape movement have erected so many rules and regulations that I don't know how people can have erotic or desire-driven sex.

Gibbs, supra note 135, at 53 (quoting Stephanie Gutmann).

166 See supra notes $155-63$ and accompanying text, explaining that men and women frequently misinterpret each other's nonverbal sexual cues. 
less of that, then we must believe that the person who touches her knows these particular ways and places instinctively, without any directives from her. ${ }^{167}$

Similarly, the idea that a woman's silence is consistent with her sexual fulfillment assumes that her partner is able intuitively to discern her sexual desires and needs correctly. Given the complexity and changeability of sexual desires and the ambiguity and imprecision of nonverbal sexual signals, this assumption seems illfounded, even absurd. Certainly it paints a picture of men as infallible sexual experts who always know just what a woman wants and "requires a theory about the dynamics of sexual pleasure that sees that pleasure as an emergent property of overwhelming male insistence." 168 The invisibility of women inherent in such views is sufficient reason for rejecting them as a model of mutual sexual enjoyment.

Not only is there no basis for the belief that silence is a necessary or desirable component of intimate encounters, but there is good reason to believe that the opposite is true. One commentator states:

Sexologists are unanimous ... in holding that mutual sexual enjoyment requires an atmosphere of comfort and communication, a minimum of pressure, and an ongoing check-up on one's partner's state .... These findings show that the way to achieve sexual pleasure, at any time at all, let alone with a casual acquaintance, decidedly does not involve overriding the other person's express reservations and providing them with just any kind of sexual stimulus. ${ }^{169}$

That is, rather than taking romance and spontaneity out of the relationship, verbal communication is likely to enhance the probability of mutually satisfactory sexual encounters. To begin with,

[s]exual interaction, particularly intercourse, is never utterly spontaneous in our culture. A couple needs to find a private location, get their clothes off, and so forth, and these activities involve two people to make decisions .... As far as romance is concerned, it is deepened ... by sharing the kind of personal

167 Pineau, supra note 12, at 228-29.

$168 \mathrm{Id}$. at 228.

$169 \mathrm{Id}$. at 231. 
information with one another that is needed for true informed consent. ${ }^{170}$

This information includes, for example, each partner's motive for participating in the encounter, information about sexually transmitted diseases, whether either partner is romantically involved with someone else, contraception, and discussion of sexual preferences. ${ }^{171}$ Even in long-term sexual relationships where this type of information is already known to both partners, intimacy can be furthered by each partner inquiring as to whether the other wishes to participate in sexual activity on a given occasion and, if so, in what sort of sexual activity he or she wishes to participate. Simply knowing that this information makes a difference to one's partner can add to comfort and trust.

A legal standard based on verbal consent would not require inquiry into all of the above-mentioned matters-to do so would be to cross the line between prohibiting nonconsensual sex and requiring fully communicative sex. Rather, the suggested legal standard only requires a man to obtain a "yes" or its verbal equivalent, the bare minimum of communication necessary to insure that sexual activity is consensual. As such, it can hardly be considered so intrusive as to "ruin the romance" of sexual encounters or place undue restriction on sexual behavior-unless one's idea of romance is the freedom not to concern oneself with one's partner's consent, and in that case one's sexual behavior should be restricted. Moreover, some change in sexual attitudes and behaviors is apparently already occurring because of increased attention to and awareness of rape. ${ }^{172}$ The proposed standard would simply accelerate this trend.

Because clear communication is likely to enhance rather than interfere with sexual enjoyment, the argument that requiring a man to obtain consent verbally would destroy the romance of sexual encounters cannot stand. The "silent is sexy" view of sexual relationships inherent in such an argument unrealistically presupposes male sexual omniscience. Even if some men insist upon viewing themselves this way "[t]he societal interest in women's

170 Allgeier \& Royster, supra note 159, at 145.

171 See id. at 144-45.

172 As one man commented, "If [men] have friends who have been threatened with charges, or they read what happens with people like Tyson, they change their habits.... The publicity about date rape certainly makes you think about the repercussions from going home with someone." Nemeth et al., supra note 4 , at 43 (statement of Ron Blair, a 26-year-old pub patron). Another commentator observed 
freedom of choice, promoted by effective communication, is sufficiently important to outweigh any possible benefits of allowing men to act in accord with what may currently be 'normal' and 'reasonable' behavior for men only by male standards." 173 Thus, there is no reason to suppose that a legal standard requiring verbal consent will take the romance out of normal, nonproblematic sexual relationships. As argued above, however, there is reason to believe that this redefinition will preserve women's sexual freedom and bring their protection under the rape law into conformity with the protection afforded victims of other crimes. A balance of these considerations therefore weighs in favor of the adoption of the suggested consent standard based on affirmative verbal consent.

\section{CONCLUSION}

"The law of sex ... can operate as a value generating force when those who create or are governed by it perceive in the law an underlying vision of appropriate sexual conduct." ${ }^{174}$ Proceeding under this premise, this Comment has set forth a consent standard informed by a belief that men and women should treat each other as equals and respect each other's bodily and sexual integrity. Discussion of such an ideal in itself is an important first step toward making its vision a reality.

that:

[ $t$ ]he public attention lavished on sexual assaults-downward from harassment through so-called date rape to gruesome rape-murders-may be transforming relations between men and women. A mindfulness that acts of affection may degenerate into cases of mental and physical trauma is provoking wary new patterns of behavior in the workplace and in private.

Mollins, supra note 142 , at 41 .

Recent behavioral changes in other areas corroborate the theory that if the consequences are severe enough, people will change even the most private and ingrained behaviors in order to avoid them. Consider for example, the public's and sexual partners' increased willingness to discuss sexual health as a result of the AIDS epidemic and its accompanying threat of death. Many people have also changed their behavior in response to increased public awareness of the issue of sexual harassment: "The ground has shifted, the dialogue is new. . . . For the first time, men and women in office corridors, nightclubs and classrooms are talking openly about the difference between date rape and consensual sex, about when dirty jokes are inappropriate and when no means no." Nemeth et al., supra note 4, at 42 . Arguably, a threat of criminal sanction for nonconsensual sex could prompt a similar change in the area of nontraditional rape.

173 Wiener, supra note 12 , at 160.

174 Chamallas, supra note 68 , at 777. 
